\title{
PSF and $\mathrm{p} 54^{\text {nrb }}$ bind a conserved stem in U5 snRNA
}

RUI PENG, ${ }^{1}$ BILLY T. DYE, ${ }^{1,2}$ ISMAEL PÉREZ, ${ }^{1}$ DARON C. BARNARD, ${ }^{1,3}$

AMANDA B. THOMPSON, ${ }^{1}$ and JAMES G. PATTON ${ }^{1}$

${ }^{1}$ Department of Biological Sciences, Vanderbilt University, Nashville, Tennessee 37235, USA

\begin{abstract}
PTB-associated splicing factor (PSF) has been implicated in both early and late steps of pre-mRNA splicing, but its exact role in this process remains unclear. Here we show that PSF interacts with $p 54^{\text {nrb }}$, a highly related protein first identified based on cross-reactivity to antibodies against the yeast second-step splicing factor Prp18. We performed RNA-binding experiments to determine the preferred RNA-binding sequences for PSF and $\mathrm{p} 54^{\mathrm{nrb}}$, both individually and in combination. In all cases, iterative selection assays identified a purine-rich sequence located on the $3^{\prime}$ side of U5 snRNA stem 1b. Filter-binding assays and RNA affinity selection experiments demonstrated that PSF and p54 ${ }^{\text {nrb }}$ bind U5 snRNA with both the sequence and structure of stem $1 \mathrm{~b}$ contributing to binding specificity. Sedimentation analyses show that both proteins associate with spliceosomes and with U4/U6.U5 tri-snPNP.
\end{abstract}

Keywords: p54 $^{\text {nrb }}$; PSF; splicing; U5 snRNA

\section{INTRODUCTION}

Most eukaryotic genes are transcribed into pre-mRNAs containing coding sequences (exons) disrupted by intervening sequences (introns). Prior to translation, the introns must be efficiently and accurately removed and the exons joined together in a process known as premRNA splicing (Burge et al., 1999; Hastings \& Krainer, 2001). Splicing is carried out within the spliceosome, a large complex composed of small nuclear ribonucleoproteins (U1, U2, U4/U6, and U5 snRNPs; Lührmann, 1988) and other non-snRNP protein factors. The joining of exons requires two transesterification reactions, the first of which involves cleavage of the $5^{\prime}$ exon and generation of a lariat intron-3' exon intermediate. The second step ligates the exons together and releases the intron. SnRNPs play important roles in both spliceosome assembly and the two catalytic steps of splicing. Dynamic base-pairing interactions between the snRNAs and the pre-mRNA and between the snRNAs themselves are crucial for accurate definition of the

Reprint requests to: James G. Patton, Department of Biological Sciences, VU Station B 351634, Vanderbilt University, Nashville, Tennessee 37235, USA; e-mail: James.G.Patton@Vanderbilt.Edu.

${ }^{2}$ Present address: Institute for Molecular Virology, University of Wisconsin-Madison, Madison, Wisconsin 53706, USA

${ }^{3}$ Present address: Department of Molecular Genetics and Microbiology, University of Massachusetts Medical School, Worcester, Massachusetts 01605, USA exon/intron boundaries (Nilsen, 1998). U1 base pairs with the $5^{\prime}$ splice site whereas U2 pairs with a region upstream of the $3^{\prime}$ splice site referred to as the branchpoint. Upon association with U4/U6.U5, a series of rearrangements occur, including dissociation of U1 from the $5^{\prime}$ splice site and dissociation of U4 from U6, allowing different regions of U6 to pair with both the $5^{\prime}$ splice site and with U2 snRNA. During these changes, U5 appears to play an important role in tethering the two exons to juxtapose them for catalysis (Newman, 1997; O'Keefe \& Newman, 1998; Alvi et al., 2001; McConnell \& Steitz, 2001).

To ensure the accuracy of splicing, these RNA rearrangements take place in a highly ordered and well-regulated manner (Reed, 2000). Although the mechanism of this is not completely understood, two groups of protein factors are thought to be involved. One contains members of a superfamily of ATPases, including the DEAD and DEAH box families. These ATPases are proposed to facilitate RNA rearrangements by unwinding RNA duplexes or by disrupting RNA-protein interactions (Staley \& Guthrie, 1998). The second group of factors are members of a family of RNA-binding proteins containing RNA recognition motifs (RRMs; Burd \& Dreyfuss, 1994; Swanson, 1995). The RRMs of these proteins are thought to mediate binding to singlestranded RNA, but RRMs also participate in proteinprotein interactions, allowing this group of factors to 
play distinct roles in annealing critical RNA pairs, stabilizing single-stranded RNAs, and facilitating exon/ intron definition (Fu, 1995; Ghetti et al., 1995; Valcárcel et al., 1996).

Most of the splicing factors that have been identified are involved in spliceosome assembly, whereas a smaller number have been proposed to function in the second step of splicing (Gozani et al., 1994; Horowitz \& Krainer, 1997; Lindsey \& Garcia-Blanco, 1998; Zhou \& Reed, 1998; Chua \& Reed, 1999). Human PTBassociated splicing factor (PSF; Patton et al., 1993) is one of these proteins. PSF is a $100-\mathrm{kDa}$ protein that colocalizes with splicing factors in nuclear speckles (Dye \& Patton, 2001), and is comprised of an N-terminal glycine-rich domain, a proline/glutamine- $(P / Q)$ rich domain, two RRMs, and a C-terminal region with two nuclear localization signals. It was first identified because of its association with polypyrimidine-tract binding protein (PTB; Patton et al., 1991), but it appears that only a fraction of PTB colocalizes with PSF (Meissner et al., 2000), and the functional relevance of this interaction has not been demonstrated. Immunodepletion of PSF from nuclear extract first suggested that PSF might play a role in early spliceosome formation (Patton et al., 1993), and subsequent depletion/repletion experiments suggested that PSF might be rate-limiting for the second step (Gozani et al., 1994). PSF copurifies with U4/ U6.U5 tri-snRNP (Teigelkamp et al., 1997), and, in addition, several studies using different purification strategies have detected PSF in both early $(\mathrm{H}, \mathrm{A}, \mathrm{B})$ and late (C) spliceosomal complexes (Bennett et al., 1992; Gozani et al., 1994; Jurica et al., 2002). Overall, the data are consistent with a role for PSF in both early and late steps of splicing, but exactly how it functions is unknown. That PSF could play multiple roles in splicing is perhaps not surprising, as it has also been implicated in transcription, topoisomerase activity, nuclear RNA retention, and DNA recombination (Straub et al., 1998, 2000; Akhmedov \& Lopez, 2000; Urban et al., 2000; Mathur et al., 2001; Zhang \& Carmichael, 2001; Sewer et al., 2002). Given the fact that many nuclear events are coupled (Maniatis \& Reed, 2002), understanding the multifunctional roles of PSF could provide insight into overall nuclear function.

Here, we performed yeast two-hybrid screens and identified $\mathrm{p} 54^{\mathrm{nrb}}$ as a PSF-interacting factor. This interaction was confirmed both by coimmunoprecipitation from HeLa nuclear extract, and by the association of recombinant proteins in vitro. We also used iterative selection techniques [systematic evolution of ligands by exponential enrichment (SELEX); Tuerk \& Gold, 1990; Szostak, 1992] to identify the optimal RNAbinding sites for PSF and p54 ${ }^{\text {nrb }}$. These experiments resulted in the selection of RNAs matching a sequence found in the $3^{\prime}$ side of a conserved stem in U5 snRNA. Both filter-binding assays and RNA affinity experiments using biotinylated U5 snRNAs demonstrated that the two proteins bind U5 snRNA with both the sequence and structure of stem $1 \mathrm{~b}$ contributing to binding specificity. Sedimentation analyses confirmed their association with spliceosomes and with U4/U6.U5 tri-snPNP.

\section{RESULTS}

\section{PSF interacts with $\mathrm{p} 54^{\mathrm{nrb}}$}

To further define the functional role of PSF, yeast twohybrid protein-protein interaction screens (Fields \& Song, 1989) were performed to identify factors that interact with PSF. A cDNA clone encoding PSF was fused to the LexA DNA-binding domain and used to screen a mouse 7-day embryo cDNA two-hybrid library fused to the VP16 transactivation domain. Sixty-three positive clones were sequenced and 29 were found to encode the mouse protein NonO (Yang et al., 1993). NonO is the mouse homolog of human p54 nrb (also referred to as nmt 55; Dong et al., 1993; Traish et al., 1997), which is very similar in sequence to PSF (Fig. 1A). For the rest of the clones, only the mouse RING Finger protein 4 (RNF4, Accession No. AF169300) and an as yet unidentified protein were identified five and six times, respectively, whereas none of the remaining clones were detected more than twice. Interestingly, separate two-hybrid screens have shown that zinc finger proteins, such as RNF4, can interact with the second RRM in PSF and may be involved in nuclear localization of PSF (Dye \& Patton, 2001).

The interaction between PSF and NonO/p54 nrb is especially interesting because the two proteins are so similar. Originally identified as a protein that crossreacts with an antibody raised against the yeast U5 snRNP-associated second-step splicing factor Prp18, p5 $4^{\mathrm{nrb}}$ is $71 \%$ identical to PSF over a region of 320 amino acids that encompasses their RRMs (Fig. 1A; Dong et al., 1993). Other homologs of PSF and p54 nrb include NonA/BJ6 from Drosophila, which has been shown to be important in Drosophila visual acuity and male courtship song (Besser et al., 1990; Jones \& Rubin, 1990), hrp65 from Chironomus tentans, a component of nuclear fibers associated with specific pre-mRNPs (Wurtz et al., 1996; Miralles et al., 2000), and PSP1 from humans, a paraspeckle protein of unknown function (Andersen et al., 2002; Fox et al., 2002).

To verify that $\mathrm{p} 54^{\mathrm{nrb}}$ interacts with PSF and to identify the regions of $\mathrm{p} 54^{\mathrm{nrb}}$ that are required for binding, coimmunoprecipitation experiments and in vitro interaction assays were performed. As shown in Figure 1B, polyclonal anti-PSF antibodies were capable of coimmunoprecipitating $\mathrm{p} 54^{\mathrm{nrb}}$ from HeLa nuclear extract, whereas $p 54^{\text {nrb }}$ was not precipitated in control reactions using nonimmune serum or protein $\mathrm{G}$ beads alone. The converse experiment using antibodies against p54 ${ }^{\text {nrb }}$ also resulted in coimmunoprecipitation (data not shown). To identify which sequences of p54 ${ }^{\text {nrb }}$ are re- 
A

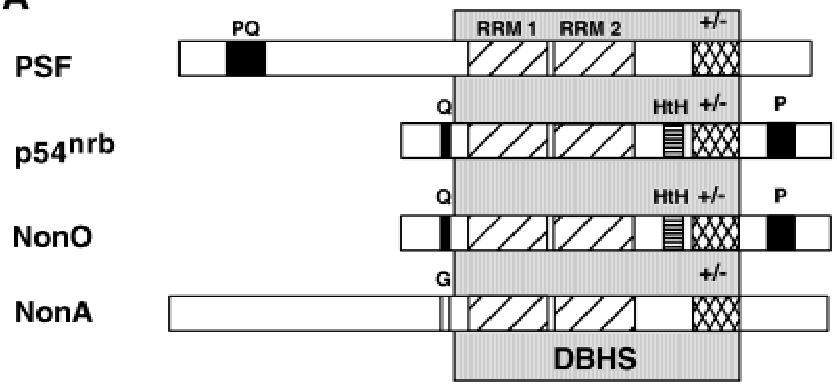

B

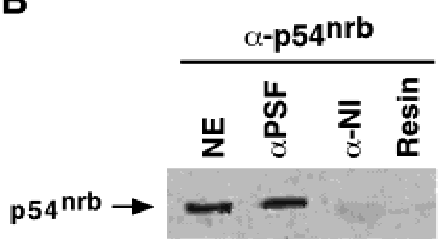

C
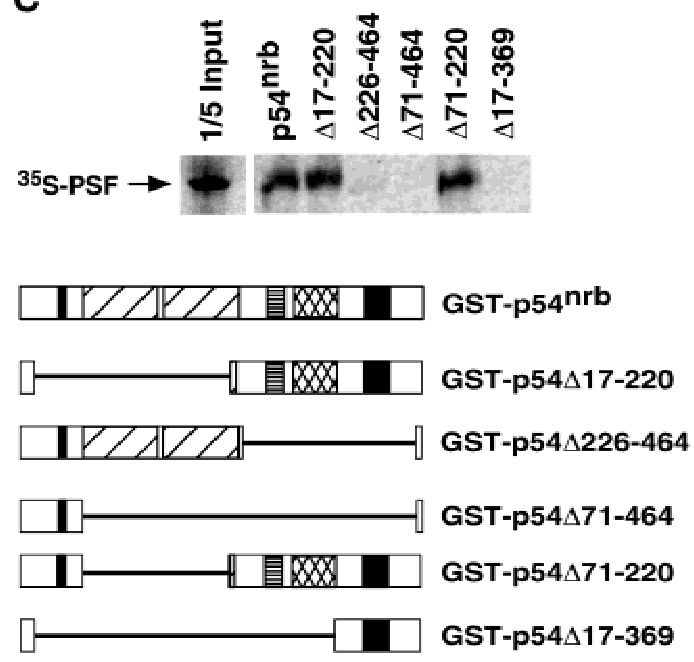

FIGURE 1. PSF-p54 nrb interaction. A: Human PSF, p54 ${ }^{\text {nrb }}$, mouse NonO, and Drosophila NonA are highly homologous over a $320-$ amino-acid region referred to as the Drosophila behavior, human splicing domain (DBHS; shaded box; Dong et al., 1993). This region includes the two RNA recognition motifs (RRM1 and RRM2, diagonally hatched boxes), a helix-turn-helix motif $(\mathrm{HtH}$, horizontally hatched boxes), and a basic/acidic region (+/-, cross-hatched boxes). Additional similarity exists in regions rich in proline $(P)$ and glutamine (Q) residues (black boxes). B: Immunoprecipitation of HeLa nuclear extract (NE) was performed with either an anti-PSF antibody $(\alpha$ PSF), nonimmune serum ( $\alpha-\mathrm{NI})$, or protein $\mathrm{G}$ beads alone (Resin). Precipitated proteins were analyzed by western blot analysis with an anti-p54 nrb antibody. C: In vitro-translated, ${ }^{35}$ S-labeled PSF was incubated with the indicated GST-p54 nrb constructs in the presence of glutathione-agarose beads. After washing, bound proteins were eluted and resolved by SDS-PAGE. Deleted regions in the GST-p54 $4^{\mathrm{nrb}} \mathrm{mu}-$ tants are represented by a thin line, with the numbers indicating the amino acid positions of the deleted residues. Domains of interest are represented as in $\mathbf{A}$.

quired for binding PSF, a series of glutathione-Stransferase-p54 $4^{\text {nrb }}$ fusion proteins (GST-p54 ${ }^{\text {nrb }}$ ) were assayed for their ability to precipitate PSF using glutathione-agarose pull-down assays (Fig. 1C). Fulllength GST-p54 ${ }^{\text {nrb }}$ and two deletion mutants (GSTp54 ${ }^{\mathrm{nrb}} \Delta 17-220$ and GST-p54 $\left.{ }^{\mathrm{nrb}} \Delta 71-220\right)$, both of which contain the putative helix-turn-helix motif and basic/ acidic region (Yang et al., 1993), were capable of binding PSF. In contrast, GST fusions that lack either or both of these regions (GST-p54 $4^{\text {nrb }} \Delta 226-464$, GSTp54 ${ }^{\text {nrb }} \Delta 71-464$, and GST-p54 ${ }^{\text {nrb }} \Delta 17-369$ ) could not precipitate PSF. Thus, it appears that the C-terminus of $\mathrm{p} 54^{\mathrm{nrb}}$ is required for its interaction with PSF. These results were corroborated by yeast two-hybrid assays, which showed that both p54 ${ }^{\mathrm{nrb}} \Delta 17-220$ and p54 ${ }^{\mathrm{nrb}} \Delta 71-$ 220 interacted with PSF in the two-hybrid system, whereas p54 ${ }^{\mathrm{nrb}} \Delta 226-464, \mathrm{p} 54^{\mathrm{nrb}} \Delta 71-464$, and p54 ${ }^{\text {nrb }} \Delta 17-369$, did not (data not shown). When the same mapping experiments were performed with a series of PSF deletion constructs, only full-length PSF was capable of interacting with $\mathrm{p} 54^{\text {nrb }}$ (data not shown). It appears that multiple contacts, or a precise tertiary structure, are needed for PSF to interact with p54 ${ }^{\mathrm{nrb}}$.

\section{Determination of the optimal RNA-binding sites of PSF and p54 $4^{\text {nrb }}$}

Iterative selection assays (Tuerk \& Gold, 1990; Szostak, 1992) were used to determine the optimal RNA binding sequence for PSF and $p 54^{\text {nrb }}$. A pool of in vitrotranscribed RNAs representing over $10^{12}$ different sequences was incubated with recombinant, hexahistidine-tagged (his-tagged) proteins, and bound RNAs were recovered by copurification over Ni-NTA agarose. Sequencing of 20 independent clones from the initial pool showed that the randomized region contained roughly equal amounts of each nucleotide (data not shown). Prior to incubation with recombinant proteins, each RNA pool was preincubated with Ni-NTA agarose to prevent enrichment of nonspecific RNAs. Following selection and amplification for eight sequential rounds, individual clones were sequenced. For PSF, simple calculation of the purine and pyrimidine content of the selected sequences showed enrichment for purines, from roughly $50 \%$ to $67 \%$ (data not shown). When the selected sequences were compared using multiple alignment algorithms, a consensus sequence was identified consisting of 5'-UGGAGAGGAAC-3' (Fig. 2A). Genomic database searches with this sequence were not particularly useful because its length is less than the number of bases needed to represent a unique sequence in the human genome. However, because PSF had been shown to copurify with U4/U6.U5 tri-snRNP, we compared the consensus sequence to these snRNAs. Strikingly, the selected sequence is identical to a region of U5 snRNA referred to as stem $1 \mathrm{~b}$ (Fig. 2D,E).

All U5 snRNAs have two stem-loop structures (Fig. 2E). The overall secondary structure and particularly the $5^{\prime}$ loop sequence are highly conserved among all eukaryotes, whereas the rest of the primary sequence is less conserved (Branlant et al., 1983; Guthrie \& Patterson, 1988). The sequence of stem $1 \mathrm{~b}$, 

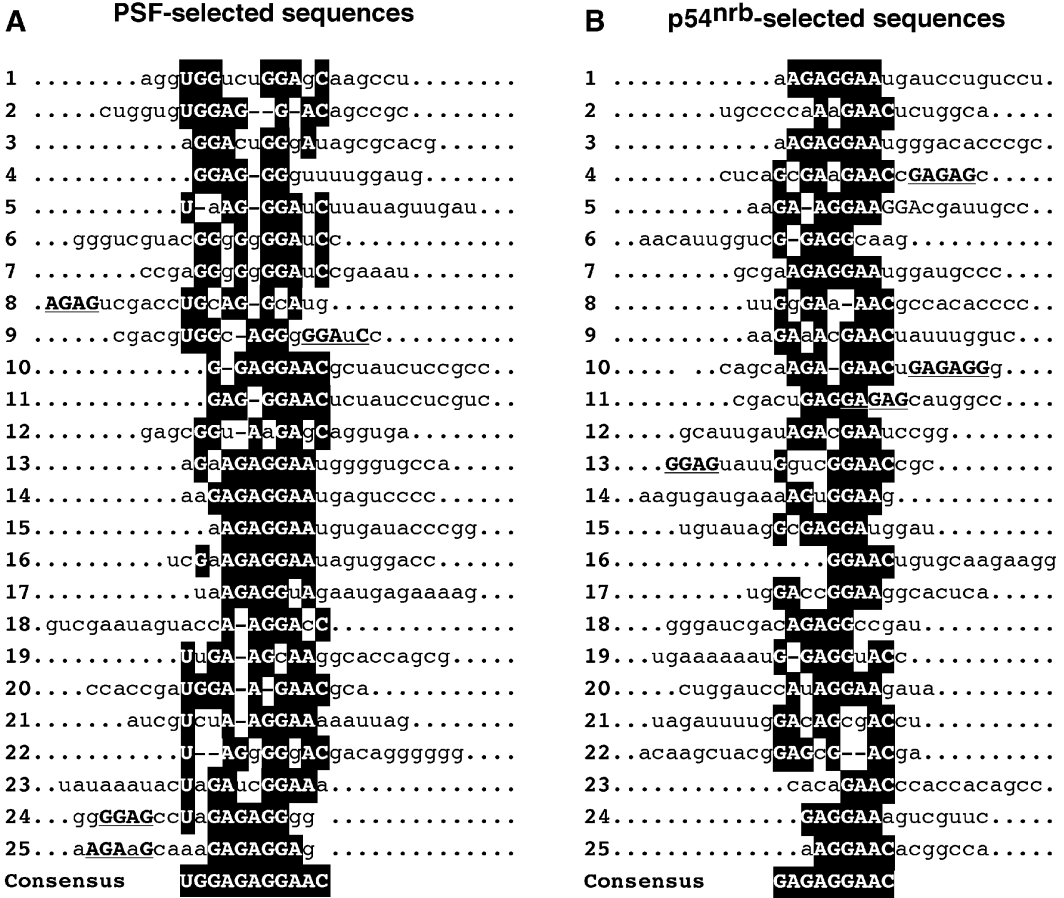

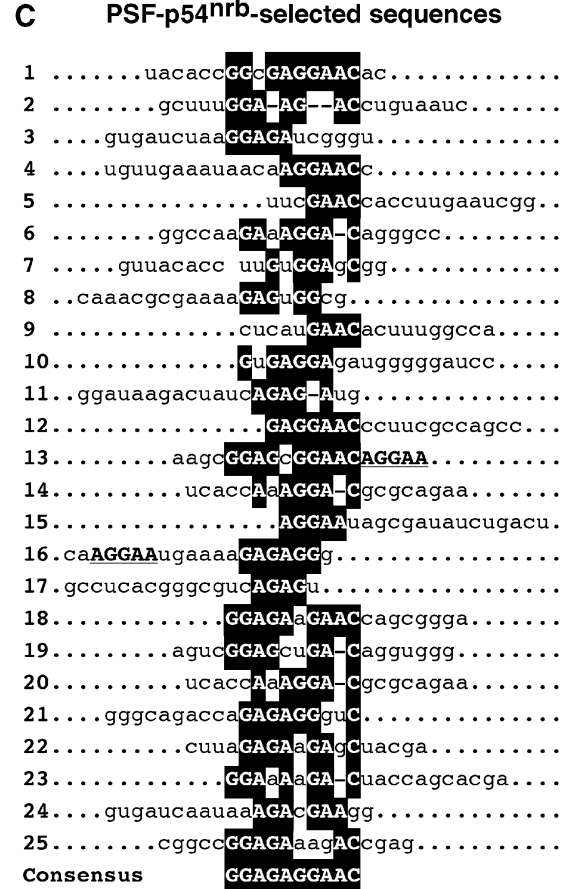

$\mathbf{E}$

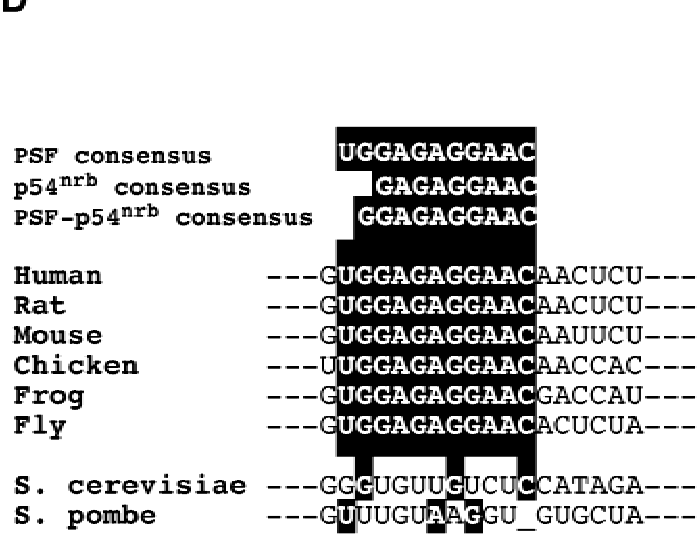

D

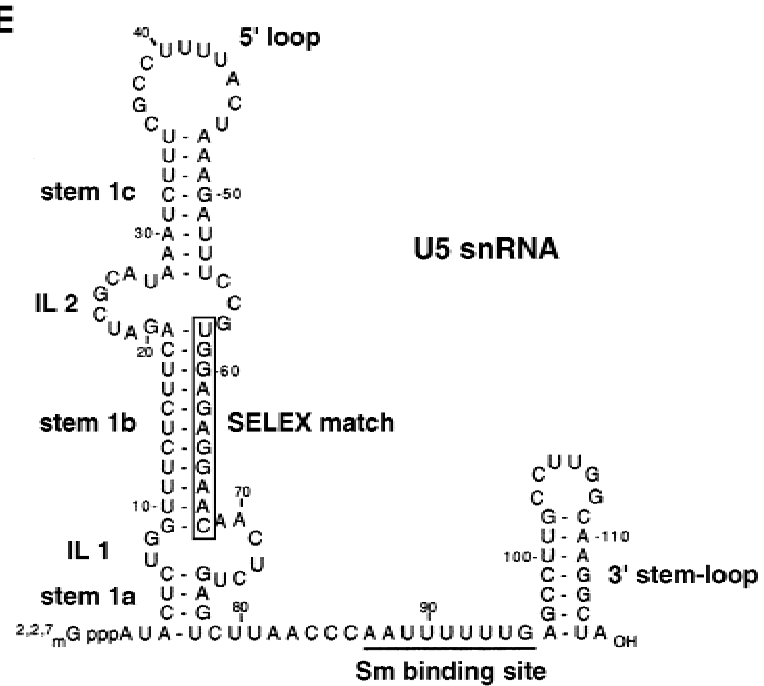

FIGURE 2. Identification of optimal RNA binding sites for PSF and p54 ${ }^{\text {nrb }}$. Iterative selection assays were performed using a pool of RNAs containing 20 randomized nucleotides and either recombinant, his-tagged PSF (A), recombinant, his-tagged p54 $4^{\mathrm{nrb}}(\mathrm{B})$, or a 1:1 mixture of PSF-p54 ${ }^{\mathrm{nrb}}(\mathbf{C})$. Eight rounds of transcription, selection, and amplification were performed before individual clones were isolated and sequenced. Alignments of the selected sequences (numbered) and the derived consensus sequences are as shown. Aligned nucleotides are displayed as capital letters on a black background, and other nucleotides that form additional alignments with the consensus sequence are in capital letters and underlined. D: Alignment of PSF and p54 ${ }^{\mathrm{nrb}}$ consensus sequences to U5 stem 1b. The PSF and p54 nrb consensus sequences are shown aligned with the $3^{\prime}$ strand of U5 snRNA stem 1b sequences from human, rat (Rattus norvegicus), mouse (Mus musculus), chicken (Gallus gallus), frog (Xenopus laevis), fly (Drosophila melanogaster), and yeast (Saccharomyces cerevisiae and Schizosaccharomyces pombe; Guthrie \& Patterson, 1988). E: The secondary structure of human U5 snRNA is depicted with the PSF RNA-binding consensus sequence boxed (adapted from Ségault et al., 1999).

including the PSF consensus sequence, is remarkably conserved from flies to humans, suggesting functional importance (Fig. 2D,E). Interestingly, this sequence is not found in the corresponding region of yeast U5 snRNA, correlating with the absence of any identified PSF homologs in Saccharomyces cerevisiae and thus far, Schizosaccharomyces pombe.
Given the high degree of homology between the RRMs of PSF and p54 $4^{\text {nrb }}$, the coimmunoprecipitation data shown in Figure 1, and previous biochemical data suggesting that these proteins exist as a heterodimer (Zhang et al., 1993; Straub et al., 1998), it was of interest to determine the optimal RNA-binding sites for p54 and mixtures of PSF-p54 ${ }^{\text {nrb }}$. As with PSF, selection with 
p54 $4^{\text {nrb }}$ or mixtures of PSF-p54 ${ }^{\text {nrb }}$ yielded sequences that also aligned well with the $3^{\prime}$ side of U5 snRNA stem 1b (Fig. 2B,C,D). This suggests that the optimal RNA-binding sites for PSF and p54 ${ }^{\text {nrb }}$, and/or mixtures thereof, are extremely similar, if not identical (Fig. 2C,D).

\section{PSF and $\mathrm{p} 54^{\mathrm{nrb}}$ form a complex with U5 snRNA in vitro}

It is possible that the RNA sequences selected by mixtures of PSF-p54 ${ }^{\text {nrb }}$ (Fig. 2C) were derived by interaction with individual proteins, or by interaction with PSF-p54 ${ }^{\text {nrb }}$ complexes. We therefore examined binding of these proteins to U5 snRNA using gel-shift assays. In vitro-transcribed, uniformly ${ }^{32} \mathrm{P}$-labeled, wildtype U5 RNA was incubated with his-tagged PSF and his-tagged $p 54^{\text {nrb }}$ (either individually or in combination), in the presence of excess yeast tRNA as nonspecific competitor, and subjected to $5 \%$ native gel electrophoresis. Upon incubation of recombinant PSF with wild-type U5, a low mobility complex was observed (Fig. 3, lane 1). This complex could be competed away by unlabeled wild-type U5 snRNA, but not yeast tRNA (data not shown), suggesting specific interaction between PSF and U5. When recombinant p54 $4^{\text {nrb }}$ was incubated with U5 by itself, no complex was detected (Fig. 3, lane 2). In contrast, incubation of 1:1 mixture of recombinant PSF and p54 ${ }^{\text {nrb }}$ with wild-type U5 resulted in a complete shift of the PSF/U5 complex to a lower mobility complex (Fig. 3, lane 3), indicating

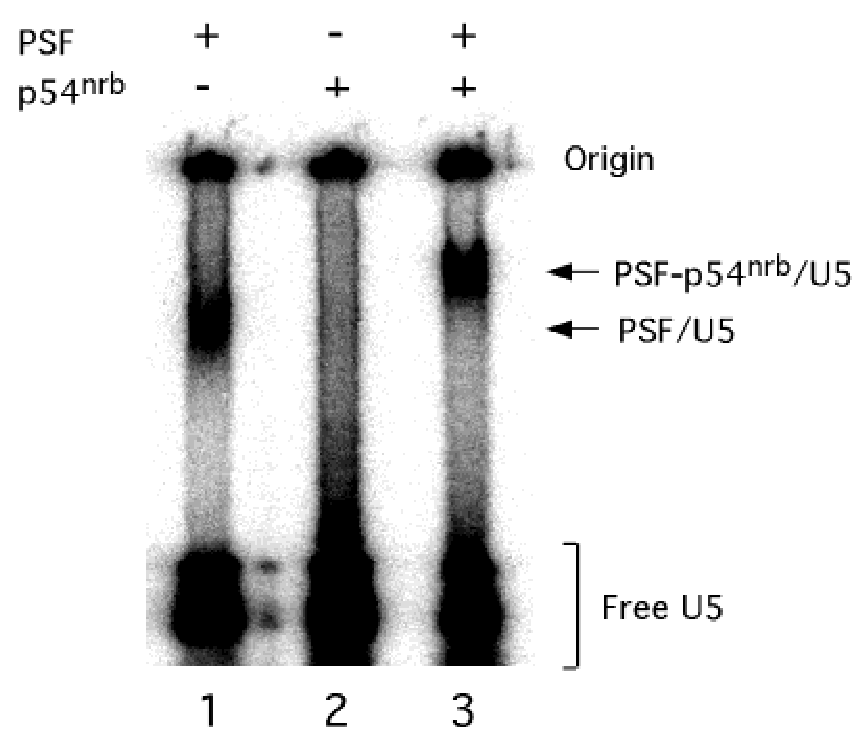

FIGURE 3. PSF and $\mathrm{p} 54^{\text {nrb }}$ form a complex with U5 snRNA in vitro. In vitro-transcribed wild-type U5 RNA was incubated with his-tagged PSF (lane 1), his-tagged p54 ${ }^{\text {nrb }}$ (lane 2), or 1:1 mixture of his-tagged PSF-p54 ${ }^{\text {nrb }}$ (lane 3) in the presence of excess yeast tRNA. The reactions were incubated at $30^{\circ} \mathrm{C}$ for $15 \mathrm{~min}$, and complex formation was analyzed by $5 \%$ native gel electrophoresis. Free RNA and proteinRNA complexes are indicated by arrows. that the two proteins form a complex with U5 snRNA simultaneously.

\section{Binding of PSF and p54 ${ }^{\text {nrb }}$ to U5 snRNA is dependent on both the sequence and structure of stem $\mathbf{1 b}$}

Proteins with RRM domains, such as PSF and p54 ${ }^{\text {nrb }}$, are thought to primarily bind single-stranded RNA. The fact that PSF and p54 $4^{\text {nrb }}$ selected single-stranded sequences that match the $3^{\prime}$ side of U5 stem $1 \mathrm{~b}$, and that they form a complex with U5 in vitro, raised the question as to whether such interaction requires melting of stem $1 b$ or whether the stem remains paired. To analyze their interaction with U5 snRNA, filter-binding assays were used. In vitro-synthesized, uniformly ${ }^{32} \mathrm{P}$ labeled, wild-type U5 snRNA was incubated with recombinant, his-tagged PSF or p54 ${ }^{\text {nrb }}$ in the presence or absence of competitor RNAs. Protein-RNA complexes were then separated from free RNA by filtration through nitrocellulose, and the level of retained U5 was quantitated. Competitor RNAs consisted of wild-type U5, U5 snRNAs containing mutations in stem $1 \mathrm{~b}$, or yeast tRNA as a nonspecific control. The different U5 snRNA mutants included a $5^{\prime}$ mutant, in which the sequence of the $5^{\prime}$ strand of stem $1 \mathrm{~b}$ was changed to disrupt the base pairing of stem $1 \mathrm{~b}$ without altering the

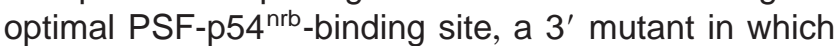
the sequence of the $3^{\prime}$ strand of stem $1 \mathrm{~b}$ was changed so that both the base pairing and the PSF-p54 ${ }^{\text {nrb }}$ binding site were disrupted, and a $5^{\prime}-3^{\prime}$ double mutant in which compensatory changes recreated stem $1 \mathrm{~b}$ but with altered sequence on both strands (Fig. 4D).

Incubation of recombinant PSF with labeled wildtype U5 led to retention of U5 snRNA on the nitrocellulose filters, whereas only small amounts of U5 were retained in the absence of protein (about $2 \%$ of total input). To ensure specificity, unlabeled wild-type U5 snRNA was included and found to effectively compete with labeled wild-type U5, reducing the binding to $30 \%$ of maximum at a fivefold molar excess of competitor RNA (Fig. 4A). In contrast, yeast tRNA showed little competition. Thus, it appears that the filter-binding assay monitors specific interaction between PSF and U5. To test whether stem $1 \mathrm{~b}$ is required for interaction with PSF, competition binding experiments were performed with the 5', 3', and 5'-3' U5 snRNA mutants. Compared to wild-type U5, the $5^{\prime}$ mutant could compete for binding but was not as effective a competitor as wildtype U5. The $3^{\prime}$ mutant showed some specificity for PSF binding but was consistently the poorest competitor at all concentrations. Surprising results were obtained with the $5^{\prime}-3^{\prime}$ mutant. We predicted that this RNA would not compete, as the PSF binding site was completely changed, but competition assays showed that it displayed a competitive efficiency similar to the $5^{\prime}$ mutant. Folding algorithms suggest that the com- 
A
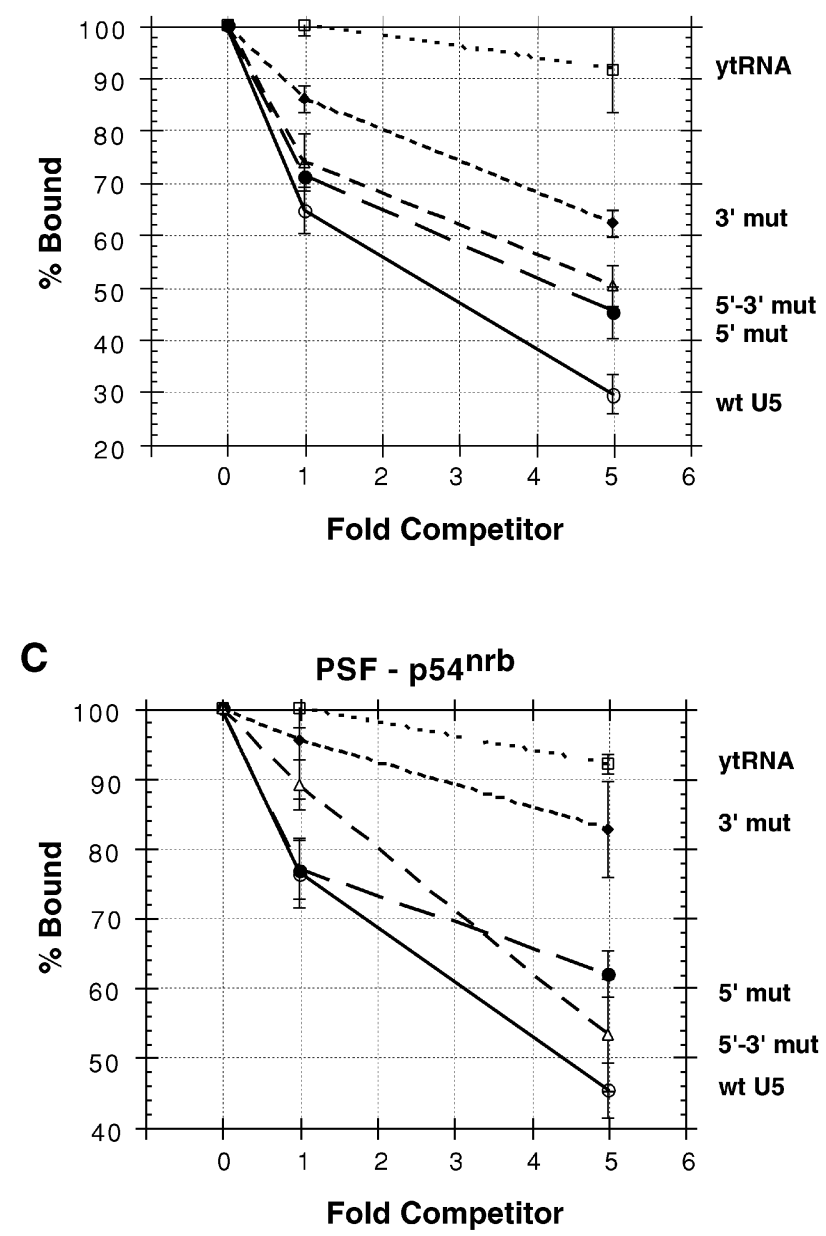

B

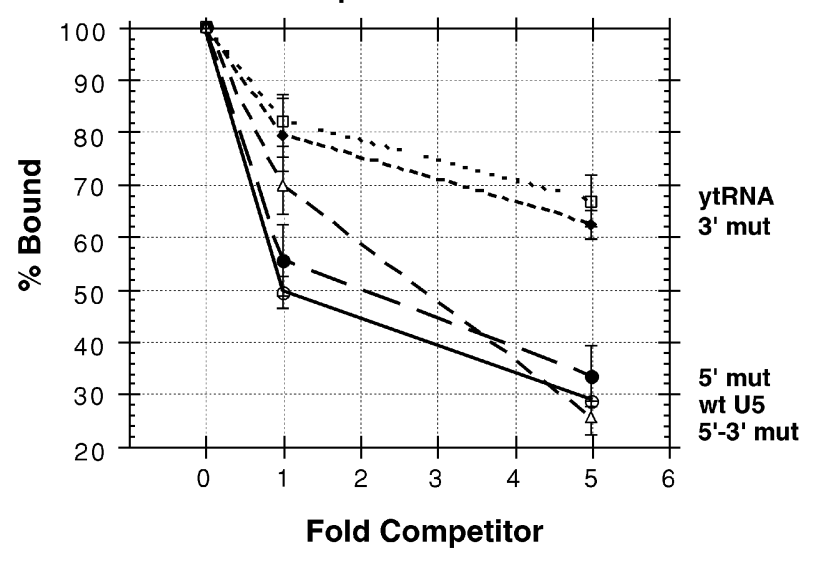

D

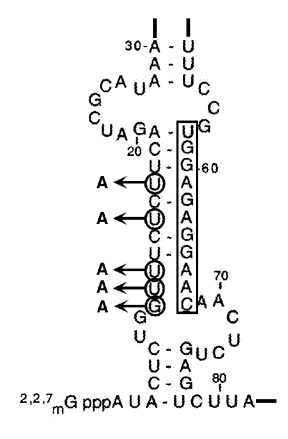

5 ' mutant

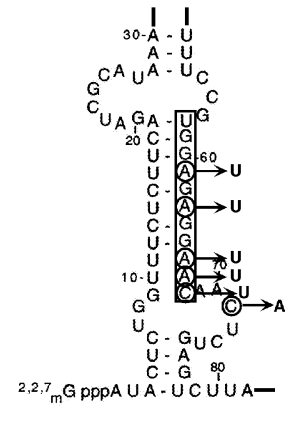

3' mutant

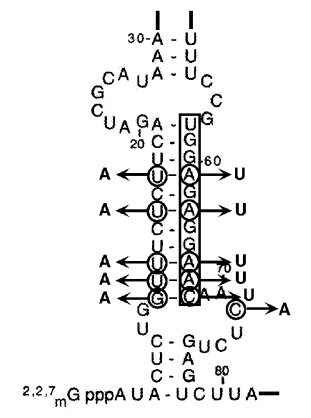

5'-3' mutant

FIGURE 4. PSF and $p 54^{\text {nrb }}$ bind U5 snRNA with both the sequence and structure of stem $1 \mathrm{~b}$ contributing to binding specificity. Filter-binding experiments were performed with radiolabeled U5 snRNA in the presence of either his-tagged PSF (A), his-tagged p54 nrb $(B)$, or a mixture of his-tagged PSF-p54 nrb $($ C). Increasing amounts of unlabeled competitor RNAs were included and the decrease in binding is shown with the indicated standard deviation $(n=3)$. Competitor RNAs: $O$, wild type (wt U5); $\bullet$, the $5^{\prime}$ mutant ( $5^{\prime}$ mut); $\bullet$, the $3^{\prime}$ mutant ( $3^{\prime}$ mut); $\triangle$, the $5^{\prime}-3^{\prime}$ mutant $\left(5^{\prime}-3^{\prime}\right.$ mut); $\square$, yeast tRNA (ytRNA). D: U5 snRNA mutants used in filter-binding experiments and RNA affinity assays. Mutated nucleotides (circled) were changed to the bases indicated by the arrows. Only the region surrounding stem $1 \mathrm{~b}$ is shown, and no additional mutations were made outside of this region. The predicted PSF-p54 ${ }^{\text {nrb }}$ binding site is boxed.

pensatory mutations recreate stem $1 \mathrm{~b}$, implying that the ability of this RNA to compete for PSF binding is due to the overall structure of the RNA rather than the sequence of the $3^{\prime}$ strand of stem $1 \mathrm{~b}$. This may explain why the $5^{\prime}$ mutant competed less efficiently than wildtype U5. Combined, the three mutant RNAs suggest that optimal binding of PSF to U5 requires both the sequence and structure of stem $1 \mathrm{~b}$.

For $\mathrm{p} 54^{\text {nrb }}$, yeast tRNA was able to partially compete with labeled wild-type U5 snRNA (Fig. 4B). Also, the 5' mutant and the $5^{\prime}-3^{\prime}$ mutant RNAs exhibited similar competitive abilities as wild-type U5 snRNA, whereas the $3^{\prime}$ mutant was no more effective than yeast tRNA. These results suggest that, in the absence of the original stem $1 \mathrm{~b}$ structure (compare the $5^{\prime}$ mutant with the $3^{\prime}$ mutant), the wild-type sequence on the $3^{\prime}$ side of the stem $1 \mathrm{~b}$ is required for specific binding of $\mathrm{p} 54^{\mathrm{nrb}}$ to U5
snRNA. However, in the presence of the original stem structure, the stem sequence is apparently less important for binding specificity (compare the $5^{\prime}-3^{\prime}$ mutant with wild-type U5). Together, the binding experiments suggest that $\mathrm{p} 54^{\mathrm{nrb}}$, like PSF, binds to U5 stem $1 \mathrm{~b}$, and that both the sequence and structure of stem $1 \mathrm{~b}$ contribute to binding specificity.

Filter-binding assays were also performed with the combination of PSF and p54 ${ }^{\text {nrb }}$ at approximately a 1:1 ratio (Fig. 4 C). Like PSF, yeast tRNA was unable to out-compete binding between the PSF-p54 ${ }^{\text {nrb }}$ complex and wild-type U5 snRNA. The $5^{\prime}-3^{\prime}$ and the $5^{\prime}$ mutant RNAs were both effective competitor RNAs, though not as efficient as wild-type U5. With the $3^{\prime}$ mutant, there was a noticeable difference in competitive efficiency using the PSF-p54 ${ }^{\text {nrb }}$ complex as opposed to the individual proteins. For the combination, the $3^{\prime}$ mutant com- 
peted only slightly better than did yeast tRNA. This suggests that the PSF-p54 $4^{\text {nrb }}$ complex, compared to each individual protein, binds U5 most efficiently when the sequence of the $3^{\prime}$ side of stem $1 b$ is wild type. However, because the $5^{\prime}-3^{\prime}$ mutant also competes, the structure of stem $1 \mathrm{~b}$ is also important for binding.

\section{PSF and $\mathrm{p} 54^{\mathrm{nrb}}$ bind U5 snRNA in nuclear extract}

The gel-shift assays and filter-binding assays described above were performed using relatively simple in vitro systems. In contrast, assembly of nuclear U5 snRNA into U5 snRNP and U4/U6.U5 tri-snRNP requires that multiple proteins interact with the RNA. To determine whether PSF and $p 54^{\text {nrb }}$ contact U5 snRNA in the presence of snRNP proteins and other factors, RNA affinity selection assays were performed using biotinylated wildtype and mutant U5 snRNAs. Following incubation of biotinylated U5 snRNAs in HeLa nuclear extract under splicing conditions, associated proteins were captured by passage over streptavidin-agarose and subjected to western blot analysis.

As shown in Figure $5, \mathrm{Sm}$ proteins $\mathrm{B} / \mathrm{B}^{\prime}$ assembled onto the different biotinylated U5 snRNAs with similar efficiency. U5 snRNP-specific proteins (U5-200 kDa and
U5-116 kDa) also associated with all U5 snRNAs with only slightly variable efficiencies between the different U5 snRNAs. Thus, both wild-type and mutant U5 snRNAs were assembled into snRNPs under these conditions. For PSF and $\mathrm{p} 54^{\text {nrb }}$, both proteins associated with U5 snRNA in nuclear extract (Fig. 5). PSF bound wild-type U5 snRNA most efficiently with slightly less association with the $5^{\prime}$ mutant, lesser association with the $5^{\prime}-3^{\prime}$ mutant, and the least association with the $3^{\prime}$ mutant. These results mirror the filter-binding results shown in Figure 4. Likewise, the association of p54 nrb with the different U5 snRNAs exhibited a similar pattern: wild type $>$ the $5^{\prime}$ mutant $>$ the $5^{\prime}-3^{\prime}$ mutant $>$ the $3^{\prime}$ mutant. As controls, neither U2AF ${ }^{65}$ (Zamore et al., 1992) nor SRrp86 (Barnard \& Patton, 2000) associated with any of the biotinylated U 5 snRNAs. These data indicate that both PSF and p54 ${ }^{\text {nrb }}$ can bind to U5 snRNA in the presence of multiple RNA-binding proteins in nuclear extract and that such interaction is dependent on the sequence and structure of stem $1 \mathrm{~b}$.

\section{PSF and p54 ${ }^{\text {nrb }}$ associate with U4/U6.U5 tri-snRNP and splicing complexes}

Because the gel-shift assays suggested that PSF and p54 ${ }^{\text {nrb }}$ might bind U5 as a complex, we next analyzed
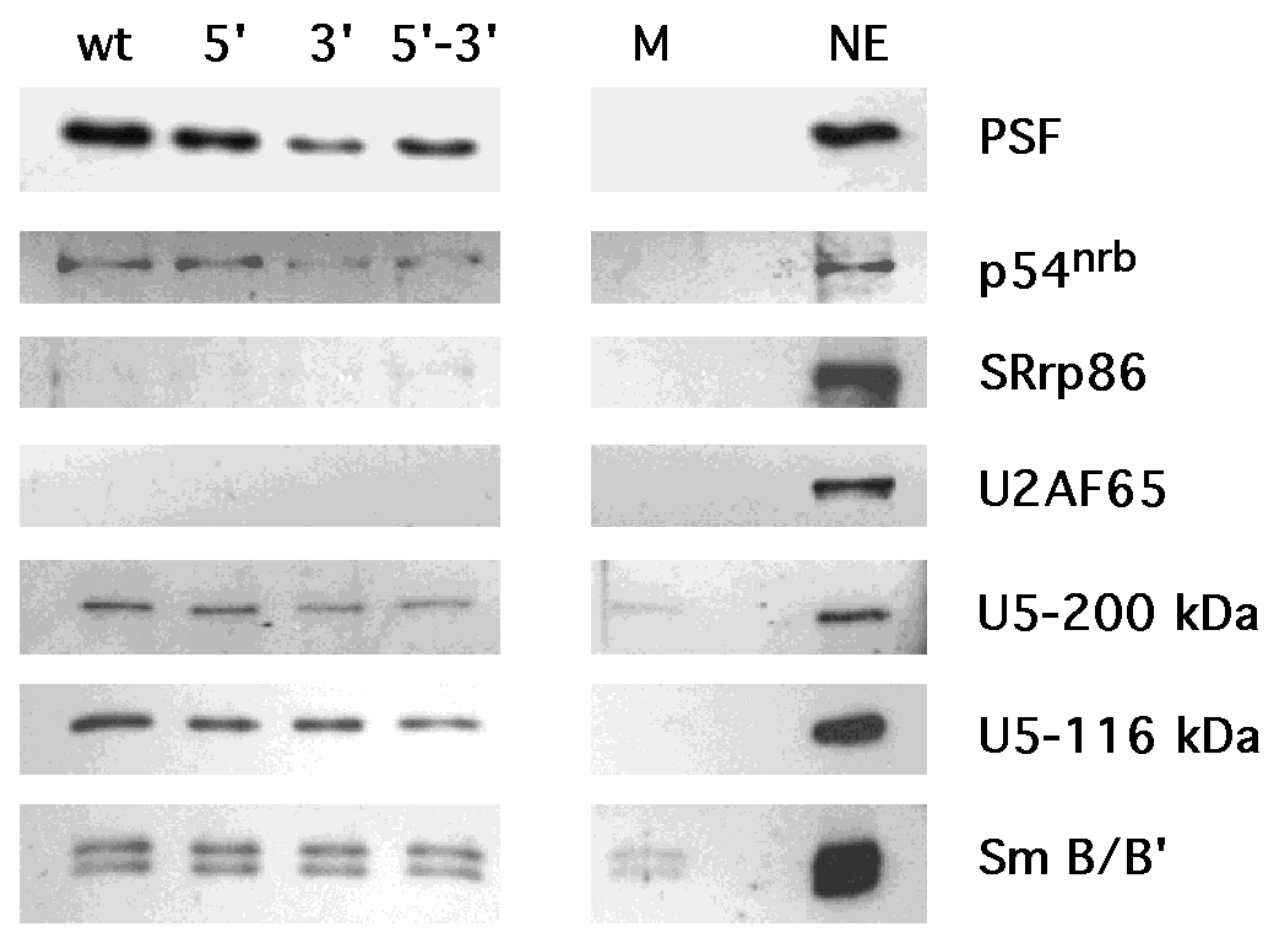

FIGURE 5. RNA affinity assays. Wild-type U 5 snRNA (U5), the $5^{\prime}$ mutant ( $\left.5^{\prime}\right)$, the $3^{\prime}$ mutant $\left(3^{\prime}\right)$, and the $5^{\prime}-3^{\prime}$ double mutant ( $5^{\prime}-3^{\prime}$; shown in Fig. 4D) were transcribed in the presence of biotin-14-CTP. Following incubation with HeLa nuclear extract (NE), biotinylated RNAs and associated proteins were captured by passage over streptavidin agarose. After extensive washing, bound proteins were eluted and resolved by SDS-PAGE. Mock reactions (M) were carried out in an identical manner without biotinylated RNA. Western blot analysis was performed using antibodies against the indicated proteins. 
the distribution of PSF and p54 nrb during splicing in HeLa nuclear extract by sucrose gradient sedimentation. Splicing reactions using labeled pre-mRNA were allowed to proceed for 15 min before separation on $10 \%-30 \%$ sucrose gradients. RNAs were extracted from each fraction and separated on a $15 \%$ denaturing gel to identify the location of both labeled splicing RNAs as well as snRNAs. Protein components of each fraction were assayed by western blot analysis. As shown in Figure $6 A, B$, pre-mRNA, mRNA, and splicing inter-

\section{A}

$10 \%-30 \%$

$\begin{array}{llllllllllllllllllll}1 & 2 & 3 & 4 & 5 & 6 & 7 & 8 & 9 & 10 & 11 & 12 & 13 & 14 & 15 & 16 & 17 & 18 & 19 & 20\end{array}$

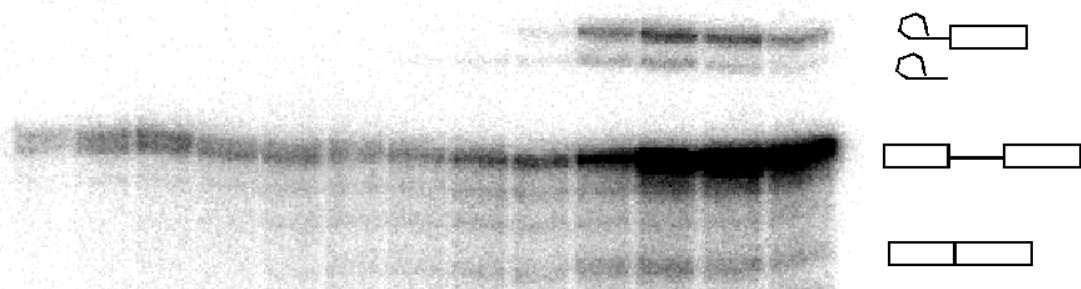

B

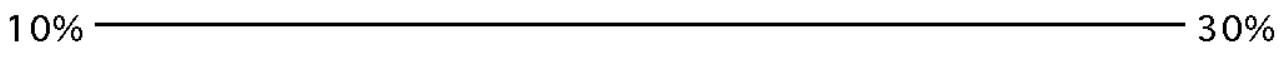

$\begin{array}{llllllllllllllllllll}1 & 2 & 3 & 4 & 5 & 6 & 7 & 8 & 9 & 10 & 11 & 12 & 13 & 14 & 15 & 16 & 17 & 18 & 19 & 20\end{array}$

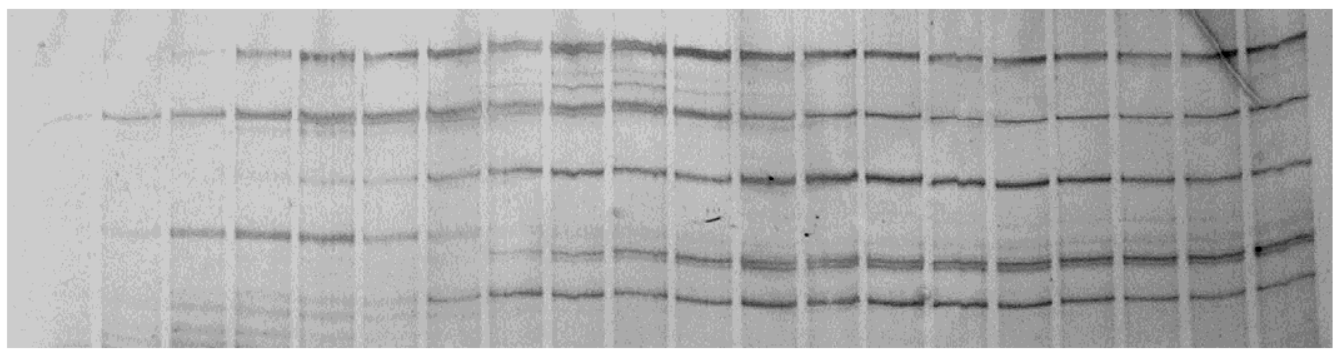

$\mathrm{U} 2$

U1

U4

U5

U6

C
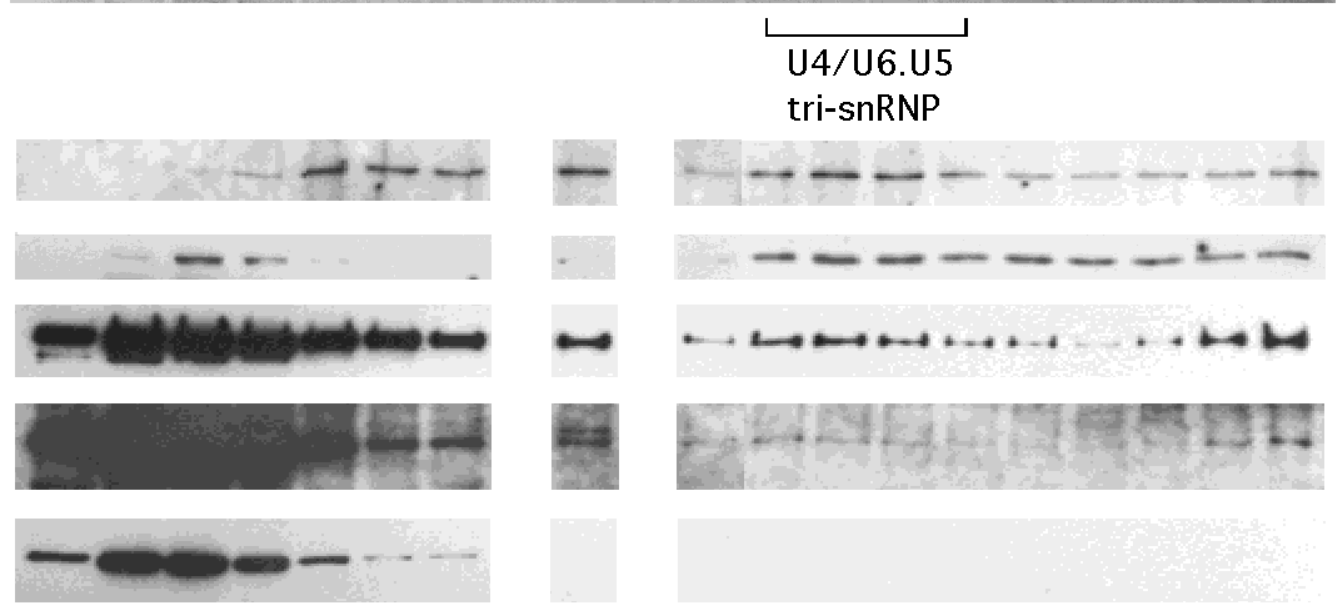

$\mathrm{U} 5-200 \mathrm{kDa}$

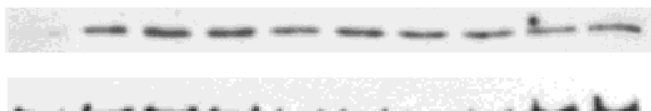

\section{U5-116 kDa}
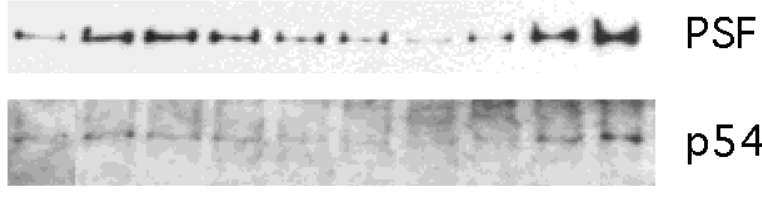

p5 $54^{\mathrm{nrb}}$
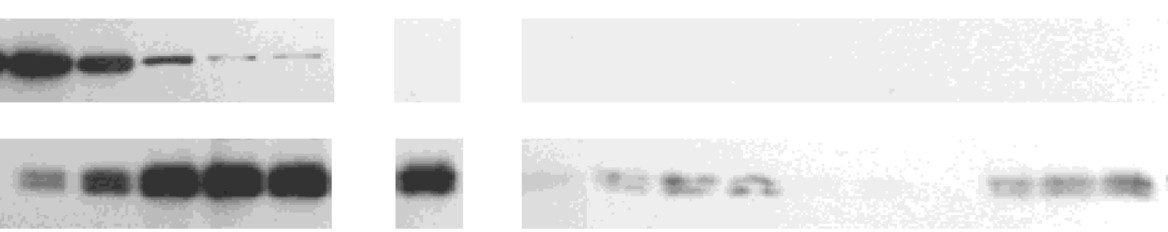

p5 $54^{\text {nrb }}$

(shorter exposure)

$B / B^{\prime}$

FIGURE 6. PSF and p54 ${ }^{\mathrm{nrb}}$ associate with U4/U6.U5 tri-snRNP and splicing complexes. Two hundred-microliter splicing reactions using AdML pre-mRNA were separated on 10\%-30\% sucrose gradients. RNAs from each fraction (numbered) were recovered by phenol/ $\mathrm{CHCl}_{3}$ extraction and separated on $8 \mathrm{M}$ urea-15\% PAGE. Splicing products and snRNAs were visualized by phosphorimager analysis $(\mathbf{A})$ and silver staining $(\mathbf{B})$, respectively. Splicing RNAs and snRNAs are indicated on the right. The position of U4/U6.U5 tri-snRNP is shown. C: Proteins from each fraction above (except fractions 8 and 10) were analyzed by western blot analysis using different antibodies as indicated. 
mediates accumulated near the bottom of the gradient along with all five $U$ snRNAs (fractions 17-20). Although the different snRNAs sedimented across the gradient, defined RNA and protein peaks could be detected that consist of free snRNPs and U4/U6.U5 trisnRNP (fractions 12-15; Fig. 6B,C). The majority of PSF and $\mathrm{p} 54^{\mathrm{nrb}}$ sedimented near the top of the gradient (fractions 2-4; Fig. 6C). However, a portion of PSF and $\mathrm{p} 54^{\mathrm{nrb}}$ comigrated with U4/U6.U5 tri-snRNP, and another subfraction cosedimented with splicing complexes (fractions 19 and 20). These results confirm that PSF and p54 ${ }^{\text {nrb }}$ associate with splicing complexes but that only a fraction of each protein cosediments with such complexes.

\section{DISCUSSION}

\section{PSF and $p 54^{n r b}$ are multifunctional interacting splicing factors}

We have demonstrated that PSF interacts with $\mathrm{p} 54^{\mathrm{nrb}}$ and that both of these proteins, individually and in combination, select the same optimal RNA-binding sequence from random pools of RNA. PSF and p54 $4^{\text {nrb }}$ share $71 \%$ identity over a 320 -amino-acid region encompassing their RRMs (Dong et al., 1993) and multiple functions have been ascribed to each. PSF copurifies with U4/U6.U5 tri-snRNP preparations (Teigelkamp et al., 1997) and a variety of biochemical experiments indicate that PSF plays an important role in pre-mRNA splicing (Patton et al., 1993; Gozani et al., 1994). In addition, roles for PSF in transcription, topoisomerase activity, nuclear RNA retention, and DNA recombination have also been postulated (Straub et al., 1998; Akhmedov \& Lopez, 2000; Straub et al., 2000; Urban et al., 2000; Mathur et al., 2001; Zhang \& Carmichael, 2001; Sewer et al., 2002). Similarly, multiple functions involving both RNA and DNA binding have been proposed for p54 ${ }^{\text {nrb }}$ (Zhang et al., 1993; Basu et al., 1997; Straub et al., 1998, 2000; Zhang \& Carmichael, 2001; Sewer et al., 2002). Several lines of evidence indicate that p54 $4^{\text {nrb }}$ is also involved in splicing. First, p54 ${ }^{\text {nrb }}$ was originally isolated in screens designed to identify proteins that cross-react with antibodies against Prp18, a yeast second-step splicing factor associated with U4/ U6.U5 tri-snRNP and U5 snRNP (Vijayraghavan \& Abelson, 1990; Dong et al., 1993; Horowitz \& Abelson, 1993). Second, GFP fusions and antibodies raised against p54 ${ }^{\text {nrb }}$ have been used to demonstrate localization to nuclei in a speckled pattern albeit somewhat more diffuse than some splicing factors (not shown). Third, overexpression of Spi-1/PU.1, an Ets-related transcription factor, blocks p54 ${ }^{\text {nrb }}$ RNA binding, which correlates with an effect on in vitro splicing (Hallier et al., 1996). Last, in this study, PSF and p54 nrb were found to cosediment with splicing complexes (Fig. 6). As to how these two proteins might function in splicing, early experiments showed that immunodepletion of PSF from splicing extracts affected both early spliceosome assembly and the second catalytic step (Patton et al., 1993; Gozani et al., 1994). More recently, PSF and p54 ${ }^{\text {nrb }}$ have been found to associate with the $5^{\prime}$ splice site (M. Konarska, pers. comm.), consistent with a recent report that $\mathrm{U} 4$ / U6.U5 tri-snRNP associates with the $5^{\prime}$ splice site (Maroney et al., 2000). It is possible that PSF and p54 nrb interact with the $5^{\prime}$ splice site early in spliceosome assembly and that this association is maintained throughout later stages of splicing, such as when the $5^{\prime}$ splice site is positioned in proximity to U5 snRNP. Thus, PSF and $\mathrm{p} 54^{\text {nrb }}$ appear to function in multiple steps of the splicing pathway, one of which may be rate-limiting for the second catalytic step. Given recent experiments suggesting a link between transcription and splicing (Monsalve et al., 2000; Fong \& Bentley, 2001; Fong \& Zhou, 2001; Maniatis \& Reed, 2002), it is also possible that the multiple roles proposed for PSF and p5 $4^{\mathrm{nrb}}$ indicate a potentially exciting link between these important nuclear functions.

\section{PSF and $\mathrm{p} 54^{\text {nrb }}$ bind a conserved stem in U5 snRNA}

SELEX experiments using PSF, p54 ${ }^{\mathrm{nrb}}$, or the combination thereof, identified a purine-rich sequence identical to the $3^{\prime}$ side of U5 snRNA stem $1 \mathrm{~b}$ as their optimal RNA binding sites (Fig. 2). Previous iterative selection assays using fewer (five) rounds of selection with p54 nrb also identified a purine-rich sequence, 5'-AGGGA-3' (Basu et al., 1997). Although this sequence is somewhat different from our results, closer examination of the selected sequences from these experiments show that they align well with U5 stem 1b. For example, 29 out of 30 clones had one or more similar GGAG or GGAA motifs, and 10 of the clones contained the sequence 5'-UGG_GAGGAA-3'. Together, the SELEX experiments suggest that both PSF and $p 54^{\mathrm{nrb}}$ bind stem $1 b$.

Binding of PSF and p54 $4^{\text {nrb }}$ to U5 was first verified by gel-shift assays, then analyzed by filter-binding assays and affinity selection experiments (Figs. 3-5). In gel-shift assays, PSF/U5 complex was completely supershifted by the addition of $p 54^{\text {nrb }}$, resulting in a PSF-p54 ${ }^{\text {nrb }} / \mathrm{U} 5$ complex (Fig. 3). Although we cannot exclude the possibility that the two proteins have individual binding sites on U5 snRNA, the fact that they selected the same sequence (the $3^{\prime}$ side of U5 snRNA stem $1 \mathrm{~b}$ ) suggests they bind to U5 stem $1 \mathrm{~b}$ as a complex, consistent with previous reports (Zhang et al., 1993; Straub et al., 1998). In agreement with this, nuclear PSF and p54 ${ }^{\text {nrb }}$ showed similar distribution patterns after sucrose gradient sedimentation (Fig. 6). In contrast, no p54 nrb/U5 complexes were observed in gel-shift assays but such interactions were clearly detectable in filter-binding experiments. Thus, $\mathrm{p} 54^{\text {nrb }}$ by itself may bind U5 snRNA 
weakly, but such interaction might be stabilized by the presence of PSF.

Binding specificity for both proteins appears to depend on multiple elements, including the predicted binding sequence on the $3^{\prime}$ side of stem $1 \mathrm{~b}$. The importance of the $3^{\prime}$ strand of the stem $1 \mathrm{~b}$ was first identified in SELEX assays and confirmed using the $5^{\prime}$ and $3^{\prime}$ mutant U5 snRNAs. In both the filter-binding assays and the biotinylated-RNA selection experiments, PSF and p54 ${ }^{\mathrm{nrb}}$ bound to wild-type U5 and the $5^{\prime}$ mutant RNA more efficiently than to the $3^{\prime}$ mutant. However, the importance of the stem structure was shown using the $5^{\prime}-3^{\prime}$ double mutant. Because the $5^{\prime}-3^{\prime}$ mutant lacks the optimal binding sequence for PSF-p5 $4^{\text {nrb }}$, it seems that the structure of stem $1 \mathrm{~b}$ contributes to binding specificity as well. Although we have not experimentally verified whether the $5^{\prime}-3^{\prime}$ mutant adopts a structure identical to wild-type $U 5$, computer folding algorithms predict the same secondary structure. Whether other factors also contribute to binding specificity remains unclear. Secondary structure predictions of the $5^{\prime}$ and $3^{\prime}$ mutants suggest that these mutations primarily affect the structure of stem $1 \mathrm{~b}$ with minor disruption of immediately adjacent structures (IL1 and IL2). The weak but detectable binding of PSF and p54 ${ }^{\text {nrb }}$ to the $3^{\prime}$ mutant implies that regions other than stem $1 \mathrm{~b}$ might also be involved in binding.

\section{Association of PSF and $\mathrm{p} 54^{\mathrm{nrb}}$ with U5 snRNA during splicing}

Double-stranded RNAs adopt the A-form conformation that precludes base-specific interaction with protein side chains in the deep major groove (Steitz, 1999). Therefore, the question arises as to how PSF and p54 ${ }^{\mathrm{nrb}}$ interact with an A-form helix while apparently maintaining sequence specificity. One speculative possibility is that PSF and p54 ${ }^{\text {nrb }}$ could bind U5 in two ways: to the intact stem, or to the $3^{\prime}$ side of the stem after melting. At least two ATPases (U5-100 kDa and U5-200 kDa) and one homolog of EF-2 GTPase (U5-116 kDa) have been found to associate with U5 snRNP and may function to mediate unwinding to facilitate the multiple RNARNA rearrangements that are central to splicing (Fabrizio et al., 1997; Teigelkamp et al., 1997; Laggerbauer et al., 1998). Interestingly, hPrp8 (U5-220 kDa), which makes multiple contacts with the pre-mRNA and with U5 (MacMillan et al., 1994; Reyes et al., 1996; Chiara et al., 1997), forms a stable complex with three U5 proteins (U5-200, U5-116, and U5-40; Achsel et al., 1998). IL2, the internal loop between stems $1 b$ and $1 c$, is required for efficient association of hPrp8 and U5-116 kDa with U5 (Hinz et al., 1996; Ségault et al., 1999). Given that the U5-200 kDa protein is a putative unwindase, it seems reasonable to propose that stem $1 \mathrm{~b}$ of U5 might also undergo a conformational change during spliceosome assembly or during the two catalytic steps. Interest- ingly, two-hybrid screens using fragments of hPrp8 have detected interaction with PSF (G. Moreau and M. Moore, pers. comm.), consistent with association of these two proteins to U5 in the vicinity of stem $1 \mathrm{~b}$.

As to how PSF and p54 ${ }^{\text {nrb }}$ might function in this process, there are at least two possibilities. First, PSF and p54 ${ }^{\text {nrb }}$ may initially bind to double-stranded stem $1 \mathrm{~b}$ but then bind more tightly to the $3^{\prime}$ side of the stem upon unwinding. Such binding could stabilize the unpaired strands coincident with U4/U6.U5 tri-snRNP contacting the $5^{\prime}$ splice site, or perhaps during the second step of splicing. Second, given that PSF has been demonstrated to promote the annealing of DNA (Akhmedov \& Lopez, 2000), PSF and p54 ${ }^{\text {nrb }}$ could facilitate the reannealing of U5 stem $1 \mathrm{~b}$ subsequent to melting, mediated by one or more unwindases. Either way, the interaction could be transient, supported by nonstoichiometric association of PSF with U4/U6.U5 tri-snRNP (Teigelkamp et al., 1997), and the fact that only a small amount of PSF and p54 ${ }^{\text {nrb }}$ cosedimented with U4/ U6.U5 tri-snRNP and with splicing complexes (Fig. 6).

The high degree of conservation of U5 stem $1 \mathrm{~b}$ in vertebrates and flies implies that it plays a critical role in U5 function. Ségault et al. (1999) examined the ability of several human U5 snRNA mutants to function in splicing by reconstituting U5-depleted nuclear extract with in vitro transcribed mutant U5 snRNAs. Although the rescue of splicing was prevented by deletion of IL2, a stem $1 \mathrm{~b}$ mutant (sub-stem $1 \mathrm{~b}$ ) was still partially functional, perhaps suggesting that this region is not important after all. However, the sub-stem 1b mutant maintained a purine-rich sequence of 5'-CAGAGA GAAGU-3' on the $5^{\prime}$ side of the stem. Comparison of this sequence with the $3^{\prime}$ strand of the original stem (the optimal PSF-p54 ${ }^{\text {nrb }}$ binding site) showed that all the changes are transitions, whereas most of our changes are transversions. Furthermore, about $50 \%$ of the SELEX sequences we identified contain at least one AGAG or GAAG motifs (Fig. 2A,B,C). Thus, it is possible that the sub-stem $1 \mathrm{~b}$ mutant fortuitously maintained a binding site for PSF and p54 ${ }^{\text {nrb }}$ on the $5^{\prime}$ side of stem $1 b$.

Unlike higher eukaryotes, the PSF-p54 ${ }^{\text {nrb }}$ binding site is not present in the corresponding regions of yeast U5 snRNA (Fig. 2D). This lack of conservation, together with the apparent absence of PSF and p54 nrb homologs in yeast, suggests either that yeast U5 functions differently from that of higher eukaryotes, or that yeast contain an as yet unidentified functional homolog of PSF and p54 ${ }^{\text {nrb }}$. Regardless, the data presented in this article show that PSF and p54 ${ }^{\mathrm{nrb}}$ interact with stem $1 \mathrm{~b}$ of U5 snRNA, requiring both the sequence and structure for binding. Detailed analysis of the effects that PSF and p54 nrb have on U5 snRNA will be required to determine the exact role these proteins play in early/ late steps of splicing, and any potential links between transcription and splicing. 


\section{MATERIALS AND METHODS}

\section{Recombinant protein expression}

Full-length human p54 ${ }^{\text {nrb }}$ was expressed from the pGex-2T vector as an N-terminal fusion with GST and from the pET 28A vector (Novagen) as a his-tagged fusion. The GSTp54 ${ }^{\text {nrb }}$ deletions described in Figure 1 (GST-p54 ${ }^{\text {nrb }} \Delta 17-220$, GST-p54 ${ }^{\text {nrb }} \Delta 71-220$, GST-p5 $4^{\text {nrb }} \Delta 17-369$, GST-p54 ${ }^{\text {nrb }} \Delta 71-$ 464, and GST-p54 226-464) were generated by reverse PCR using pGex-2T-p54 ${ }^{\text {nrb }}$ as the template (Imai et al., 1991; Coolidge \& Patton, 1995). Detailed cloning strategies and primer sequences are available upon request. All clones were verified by sequencing.

GST-p54 ${ }^{\text {nrb }}$ and deletion mutants were expressed in the Escherichia coli strain HB101, and pET 28A-p54 ${ }^{\text {nrb }}$ was expressed in BL21 (DE3)-pLysS. Cells were grown in LB media at $37^{\circ} \mathrm{C}$ until an $\mathrm{OD}_{600}$ of 0.5 was attained. Expression was induced for $3 \mathrm{~h}$ by the addition of IPTG to a final concentration of $1 \mathrm{mM}$. GST-p54 ${ }^{\text {nrb }}$ fusion proteins were purified by passage over glutathione agarose (Sigma), eluted with a glutathione gradient, and dialyzed against buffer D (20 mM Tris$\mathrm{HCl}, \mathrm{pH}$ 7.9, $100 \mathrm{mM} \mathrm{KCl,} 0.2$ mM EDTA, 0.5 mM DTT, 5\% glycerol). His-tagged $\mathrm{p} 54^{\text {nrb }}$ was purified by passage over Ni-NTA agarose (Qiagen) and further purified by chromatography on a Mono-S column (Pharmacia). His-tagged PSF was prepared as previously described (Patton et al., 1993) with additional purification over a Mono-S column. Average purity of the proteins was $95 \%$. Purified proteins were dialyzed into either buffer A (Pérez et al., 1997) for use in SELEX assays or into buffer $D$ for other experiments.

\section{Yeast two-hybrid screens}

Full-length PSF cDNA was cloned into the pBTM116 vector as a fusion with the LexA DNA binding domain and used to screen a 7-day mouse embryo cDNA library cloned into pVP16 and expressed as fusions with the VP16 transcriptional activation domain. Bait and prey vectors were cotransformed into the yeast strain L40 (his3 $\Delta 200$, trp-901, leu2-3, 112, ade2, LYS2::(lexAop) ${ }_{4}$-HIS3, URA3::(lexAop) 8 -LacZ, partial genotype), allowing selection of positive interactions based on growth on his ${ }^{-}$plates and $\beta$-galactosidase activity. Initial selection for positive clones was performed on his ${ }^{-}$plates containing a final concentration of $15 \mathrm{mM}$ 3-amino-triazole. $\beta$-galactosidase assays were performed as previously described (Kaiser et al., 1994).

\section{Immunoprecipitations}

HeLa nuclear extract (approximately $50 \mu \mathrm{g}$; Abmayr et al., 1988) was diluted to a volume of $400 \mu \mathrm{L}$ with buffer D containing $0.5 \%$ NP-40 and incubated with $1.2 \mu \mathrm{g}$ anti-PSF antibody (Patton et al., 1993) and $15 \mu \mathrm{L}$ (bead volume) protein G-Sepharose (Pharmacia) for $2 \mathrm{~h}$ at $4{ }^{\circ} \mathrm{C}$. Following three washes with buffer D containing $0.5 \%$ NP-40, beads were resuspended in $20 \mu \mathrm{L} 2 \times$ Laemmli loading buffer (Laemmli, 1970). Following separation on 9\% SDS-PAGE gels, immunoprecipitated proteins were transferred to PVDF, and p54 ${ }^{\mathrm{nrb}}$ was detected by western blot analysis using a monoclonal antibody raised against GST-p54 ${ }^{\text {nrb }}$.

\section{PSF-p54 ${ }^{\text {nrb }}$ interaction assays}

In vitro-translated, ${ }^{35}$ S-labeled PSF was prepared using the TNT ${ }^{\circledR}$ T7 Coupled Reticulocyte Lysate System (Promega). The radiolabeled protein was diluted in PP-300 buffer $(20 \mathrm{mM}$ Tris- $\mathrm{HCl}, \mathrm{pH} 8.0,300 \mathrm{mM} \mathrm{NaCl}, 0.5 \mathrm{mM}$ EDTA, 0.2\% NP-40, and $0.5 \mathrm{mM}$ DTT) and mixed with equal amounts of glutathione-agarose beads to which GST-p54 ${ }^{\text {nrb }}$ or one of its deletion mutant derivatives was prebound. Following incubation in a total volume of $225 \mu \mathrm{L}$ at room temperature for $1 \mathrm{~h}$, the beads and bound proteins were precipitated by brief centrifugation, and the supernatant was discarded. The beads were then washed three times with $500 \mu \mathrm{L}$ of PP-300 and resuspended in $30 \mu \mathrm{L}$ of $2 \times$ Laemmli loading buffer (Laemmli, 1970). Bound proteins were resolved by SDS-PAGE on $9 \%$ gels, and radiolabeled PSF visualized by phosphorimager analysis.

\section{SELEX}

SELEX assays were performed using $7.5 \mu \mathrm{g}$ of each recombinant protein in the binding steps, as described (Tuerk \& Gold, 1990; Pérez et al., 1997). Briefly, a pool of DNA (5'-GCGTCTCGAGAAGCTTCC $\left(\mathrm{N}_{20}\right)$ AGTCGGGAATTCGG ATCCCtatagtgagtcgtatta-3') was synthesized containing a randomized 20-nt sequence $\left(\mathrm{N}_{20}\right)$ flanked by anchor sequences that served as primer annealing sites for PCR and for T7 RNA polymerase. The amplified DNA pool was then transcribed, and resulting RNAs were incubated with histagged PSF and/or his-tagged p54 ${ }^{\text {nrb }}$ in binding buffer $(10 \mathrm{mM}$ Tris- $\mathrm{HCl}, \mathrm{pH} 7.5,100 \mathrm{mM} \mathrm{KCl}, 2.5 \mathrm{mM} \mathrm{MgCl}_{2}, 0.1 \%$ Triton $\mathrm{X}-100,0.1 \mathrm{mg} / \mathrm{mL}$ yeast tRNA). The proteins and bound RNAs were recovered with Ni-NTA agarose beads (Qiagen) and RNAs were recovered by phenol extraction and ethanol precipitation. Selected RNAs were then reverse transcribed and amplified by PCR to produce an enriched pool of DNA. After eight rounds of selection, reverse transcription, and amplification, the final pool was cloned and sequenced. Prior to selection, each pool of RNA was incubated with Ni-NTA agarose to eliminate nonspecific binding to the beads. Consensus sequences were generated using the GCG DNA analysis software.

\section{In vitro transcription}

The 5', 3', and 5' $-3^{\prime}$ human U5 snRNA mutants described in Figure 4D were generated by site-directed mutagenesis from pHU5a2 (wild type; Patton, 1991) as described (Imai et al., 1991; Coolidge \& Patton, 1995). All mutants were confirmed by sequencing, and their secondary structures analyzed by both Mfold3 (Mathews et al., 1999; Zuker et al., 1999; http:// bioinfo.math.rpi.edu/\%7Emfold/rna/form1.cgi) and the Vienna package (Hofacker et al., 1994; http://www.tbi.univie.ac.at/ cgi-bin/RNAfold.cgi). Wild type, ${ }^{32}$ P-CTP-labeled, U5 snRNA, unlabeled competitor RNAs, and biotinylated RNAs were transcribed from templates (Bfal-linearized pHU5a2) using the SP6 MEGAscript ${ }^{\mathrm{TM}}$ in vitro transcription kit (Ambion). Template DNAs were removed by digestion with RNase-free DNase I. Biotin was uniformly incorporated by the addition of biotin-14CTP (Invitrogen), as described (Dye et al., 1998). An adenovirus-derived splicing substrate RNA (AdML) was transcribed as described (Dye et al., 1998; Barnard \& Patton, 2000). 


\section{Gel-shift assays}

Radiolabeled wild-type U5 snRNA (1.3 pmol) was mixed with 5.8 pmol his-tagged PSF and/or 5.8 pmol his-tagged p54 nrb in reactions containing $1 \mathrm{mM} \mathrm{ATP,} 2 \mathrm{mM} \mathrm{MgCl}_{2}, 0.5 \mathrm{mM}$ DTT, $0.4 \mathrm{mg} / \mathrm{mL}$ yeast tRNA, and enough buffer $D$ to reach $60 \mathrm{mM}$ $\mathrm{KCl}$ in a total volume of $10 \mu \mathrm{L}$. Reactions were incubated at $30^{\circ} \mathrm{C}$ for $15 \mathrm{~min}$, and then stored on ice for additional $5 \mathrm{~min}$. Samples were separated on $5 \%$ nondenaturing polyacrylamide gels ( $50 \mathrm{mM}$ Tris, $50 \mathrm{mM}$ glycine; Konarska \& Sharp, 1987). Gels were dried and protein-RNA complexes visualized by phosphorimager analysis.

\section{Nitrocellulose filter-binding assays}

Filter-binding assays were performed as described (Lynch \& Maniatis, 1995). Radiolabeled wild-type U5 snRNA (5 pmol) was incubated with 2 pmol his-tagged PSF and/or 2 pmol his-tagged p54 nrb in reactions containing $1 \mathrm{mM}$ ATP, $2 \mathrm{mM}$ $\mathrm{MgCl}_{2}, 0.5 \mathrm{mM}$ DTT, $0.4 \mathrm{mg} / \mathrm{mL}$ yeast tRNA, enough buffer $D$ to reach $60 \mathrm{mM} \mathrm{KCl}$, and the indicated amount of unlabeled competitor RNA in a total volume of $10 \mu \mathrm{L}$. The amount of labeled RNA bound to filters was monitored by control reactions in which Buffer $D$ was substituted for proteins. Reactions were incubated at $30^{\circ} \mathrm{C}$ for $15 \mathrm{~min}$, and then stored on ice for additional $5 \mathrm{~min}$. Samples were diluted with $90 \mu \mathrm{L}$ wash buffer (12 mM Tris- $\mathrm{HCl}, \mathrm{pH} 7.9,60 \mathrm{mM} \mathrm{KCl}, 0.12 \mathrm{mM}$ EDTA), and immediately filtered through a $0.45 \mu \mathrm{m}$ pore nitrocellulose sandwiched in a Hybri-Slot ${ }^{\mathrm{TM}}$ manifold (Gibco$B R L)$. Filters were washed once with $200 \mu \mathrm{L}$ wash buffer, air-dried, and the amount of retained, labeled U5 was quantitated.

\section{RNA affinity assays}

HeLa nuclear extract ( $15 \mu \mathrm{L}$, approximately $75 \mu \mathrm{g}$ ) was incubated with $1 \mu \mathrm{g}$ biotinylated RNA in each $50 \mu \mathrm{L}$ reaction containing $0.5 \mathrm{mM}$ ATP, $20 \mathrm{mM}$ phosphocreatine, $2 \mathrm{mM} \mathrm{MgCl}_{2}$, $0.5 \mathrm{mM}$ DTT, $15 \mu \mathrm{L}$ buffer $\mathrm{D}$, and $0.3 \mathrm{mg} / \mathrm{mL}$ yeast tRNA. Reactions were incubated for $15 \mathrm{~min}$ at $30^{\circ} \mathrm{C}$, chilled on ice for $5 \mathrm{~min}$, and then mixed with $20 \mu \mathrm{L}$ streptavidin-agarose beads (Sigma), preequilibrated in $130 \mu \mathrm{L}$ wash buffer (see above) containing $1 \mathrm{mM} \mathrm{PMSF}, 50 \mu \mathrm{g} / \mathrm{mL}$ yeast tRNA, $0.01 \%$ NP-40. All samples were placed in $50 \mathrm{~mL}$ tubes packed with ice, and rocked on a tilt board at $4^{\circ} \mathrm{C}$ for $30 \mathrm{~min}$. Beads were then washed twice with $200 \mu \mathrm{L}$ ice-cold wash buffer containing $0.005 \%$ NP-40 and resuspended in $2 \times$ Laemmli loading buffer (Laemmli, 1970). Following SDS-PAGE on $10 \%$ gels (or 5\% gels for U5-200 kDa and U5-116 kDa), proteins were transferred to nitrocellulose, and western blots were performed using either anti-PSF (Patton et al., 1993), antip54 ${ }^{\text {nrb }}$, anti-U5-116 kDa (Fabrizio et al., 1997), anti-U5-200 $\mathrm{kDa}$ (Lauber et al., 1996), anti-snRNP (from human patients), anti-SRrp86 (Barnard \& Patton, 2000), or polyclonal anti$\mathrm{U} 2 \mathrm{AF}^{65}$ antibodies.

\section{Sucrose gradient sedimentation of snRNPs and splicing complexes}

In vitro splicing reactions using AdML pre-mRNA were carried out as previously described (Barnard \& Patton, 2000). For sedimentation analyses, $200 \mu \mathrm{L}$ splicing reactions were incubated at $30^{\circ} \mathrm{C}$ for $15 \mathrm{~min}$, and then layered onto $10 \%-30 \%$ sucrose gradients containing $2 \mathrm{mM} \mathrm{MgCl}_{2}, 0.5 \mathrm{mM} \mathrm{DTT}, 60 \%$ buffer D, $1 \mathrm{mM}$ PMSF, $5 \mathrm{mM} \mathrm{NaF}$, and $0.01 \% \mathrm{NP}-40$. After centrifugation in a Beckman SW-60 rotor at 25,000 rpm for $14 \mathrm{~h}$ at $4{ }^{\circ} \mathrm{C}$, fractions from the gradients were collected. RNAs were recovered from each fraction by phenol/ $\mathrm{CHCl}_{3}$ extraction and separated on $8 \mathrm{M}$ urea-15\% PAGE. Splicing products and snRNAs were visualized by phosphorimager analysis and silver staining, respectively. Proteins from each fraction were analyzed by western blot analysis using different antibodies as described above.

\section{ACKNOWLEDGMENTS}

We thank Melissa Moore and Maria Konarska for sharing unpublished results, and Jun Li for suggestions and comments. We also thank Jeff Patton for the human U5 snRNA construct (pHU5a2), and Patrizia Fabrizio for U5 snRNPspecific antibodies (anti-U5-116 and anti-U5-200). This work was supported by funds from the National Science Foundation (MCB-997452). I.P. was supported by a MARC grant from the National Institutes of Health.

Received February 4, 2002; returned for revision February 26, 2002; revised manuscript received July 22, 2002

\section{REFERENCES}

Abmayr SM, Workman JL, Roeder RG. 1988. The pseudorabies immediate early protein stimulates in vitro transcription by facilitating TFIID:promoter interactions. Genes \& Dev 2:542-553.

Achsel T, Ahrens K, Brahms H, Teigelkamp S, Lührmann R. 1998. The human U5-220kD protein (hPrp8) forms a stable RNA-free complex with several U5-specific proteins, including an RNA unwindase, a homologue of ribosomal elongation factor EF-2, and a novel WD-40 protein. Mol Cell Biol 18:6756-6766.

Akhmedov AT, Lopez BS. 2000. Human 100-kDa homologous DNApairing protein is the splicing factor PSF and promotes DNA strand invasion. Nucleic Acids Res 28:3022-3030.

Alvi R, Lund M, O'Keefe RT. 2001. ATP-dependent interaction of yeast U5 snRNA loop 1 with the 5' splice site. RNA 7:1013-1023.

Andersen JS, Lyon CE, Fox AH, Leung AKL, Lam YW, Steen H, Mann M, Lamond Al. 2002. Directed proteomic analysis of the human nucleolus. Curr Biol 12:1-11.

Barnard DC, Patton JG. 2000. Identification and characterization of a novel serine-arginine-rich splicing regulatory protein. Mol Cell Biol 20:3049-3057.

Basu A, Dong B, Krainer AR, Howe CC. 1997. The intracisternal A-particle proximal enhancer-binding protein activates transcription and is identical to the RNA- and DNA-binding protein p54nrb/ NonO. Mol Cell Biol 17:677-686.

Bennett M, Michaud S, Kingston J, Reed R. 1992. Protein components specifically associated with prespliceosome and spliceosome complexes. Genes \& Dev 6:1986-2000.

Besser HV, Schnabel P, Wieland C, Fritz E, Stanewsky R, Saumweber H. 1990. The puff-specific Drosophila protein Bj6, encoded by the gene no-on transient $A$, shows homology to RNA-binding proteins. Chromosoma 100:37-47.

Branlant C, Krol A, Lazar E, Haendler B, Jacob M, Galego-Dias L, Pousada C. 1983. High evolutionary conservation of the secondary structure and of certain nucleotide sequences of U5 RNA. Nucleic Acids Res 11:8359-8367.

Burd CG, Dreyfuss G. 1994. Conserved structures and diversity of functions of RNA-binding proteins. Science 265:615-621.

Burge CB, Tuschl T, Sharp PA. 1999. Splicing of precursors to mRNAs 
by spliceosomes. In: Gesteland RF, Cech TR, Atkins JF, eds. The RNA world. Cold Spring Harbor, New York: Cold Spring Harbor Laboratory Press. pp 525-560.

Chiara MD, Palandjian L, Krämer RF, Reed R. 1997. Evidence that U5 snRNP recognizes the $3^{\prime}$ splice site for catalytic step II in mammals. EMBO J 16:4746-4759.

Chua K, Reed R. 1999. Human step II splicing factor hSlu7 functions in restructuring the spliceosome between the catalytic steps of splicing. Genes \& Dev 13:841-850.

Coolidge CJ, Patton JG. 1995. Run-around PCR: A novel way to create duplications using polymerase chain reaction. Biotechniques 18:763-764.

Dong B, Horowitz DS, Kobayashi R, Krainer AR. 1993. Purification and cDNA cloning of HeLa cell p5 $4^{\text {nrb }}$, a nuclear protein with two RNA recognition motifs and extensive homology to human splicing factor PSF and Drosophila NONA/BJ6. Nucleic Acids Res 21:4085-4092.

Dye BT, Buvoli M, Mayer SA, Lin C-H, Patton JG. 1998. Enhancer elements activate the weak 3 ' splice site of $\alpha$-tropomyosin Exon 2. RNA 4:1523-1536.

Dye BT, Patton JG. 2001. An RNA recognition motif (RRM) is required for the localization of PTB-associated splicing factor (PSF) to subnuclear speckles. Exp Cell Res 263:131-144.

Fabrizio P, Laggerbauer B, Lauber J, Lane WS, Lührmann R. 1997. An evolutionarily conserved U5 snRNP-specific protein is a GTPbinding factor closely related to the ribosomal translocase EF-2. EMBO J 16:4092-4106.

Fields S, Song O-k. 1989. A novel genetic system to detect proteinprotein interactions. Nature 340:245-246.

Fong N, Bentley DL. 2001. Capping, splicing, and 3' processing are independently stimulated by RNA polymerase II: Different functions for different segments of the CTD. Genes \& Dev 15:17831795.

Fong YW, Zhou Q. 2001. Stimulatory effect of splicing factors on transcriptional elongation. Nature 414:929-933.

Fox AH, Lam YW, Leung AKL, Lyon CE, Andersen J, Mann M, Lamond Al. 2002. Paraspeckles; A novel nuclear domain. Curr Biol 12:13-25.

Fu X-D. 1995. The superfamily of arginine/serine-rich splicing factors. RNA 1:663-680.

Ghetti A, Company M, Abelson JN. 1995. Specificity of Prp24 binding to RNA: A role for Prp24 in the dynamic interaction of $\mathrm{U} 4$ and $\mathrm{U} 6$ snRNAs. RNA 1:132-145.

Gozani O, Patton JG, Reed R. 1994. A novel set of spliceosomeassociated proteins (SAPs) and the essential splicing factor PSF bind stably to pre-mRNA prior to catalytic step II of the splicing reaction. EMBO J 13:3356-3367.

Guthrie C, Patterson B. 1988. Spliceosomal snRNAs. Annu Rev Genet 22:387-419.

Hallier M, Tavitian A, Moreau-Gachelin F. 1996. The transcriptional factor Spi-1/PU.1 binds RNA and interferes with the RNA-binding protein p54 ${ }^{\text {rrb }}$. J Biol Chem 271:11177-11181.

Hastings ML, Krainer AR. 2001. pre-mRNA splicing in the new millennium. Curr Opin Cell Biol 13:302-309.

Hinz M, Moore MJ, Bindereif A. 1996. Domain analysis of human U5 RNA. J Biol Chem 271:19001-19007.

Hofacker IL, Fontana W, Stadler PF, Bonhoeffer S, Tacker M, Schuster P. 1994. Fast folding and comparison of RNA secondary structures. Monatshefte f. Chemie 125:167-188.

Horowitz DS, Abelson J. 1993. A U5 small nuclear ribonucleoprotein particle protein involved in the second step of pre-mRNA splicing in S. cerevisiae. Mol Cell Biol 13:2959-2970.

Horowitz DS, Krainer AR. 1997. A human protein required for the second step of pre-mRNA splicing is functionally related to a yeast splicing factor. Genes \& Dev 11:139-151.

Imai Y, Matshushima Y, Sugimura T, Terada M. 1991. A simple and rapid method for generating a deletion by PCR. Nucleic Acids Res 19:2785.

Jones KR, Rubin GM. 1990. Molecular analysis of no-on-transient A, a gene required for normal vision in Drosophila. Neuron 4:711-723.

Jurica MS, Licklider LJ, Gygi SR, Grigorieff N, Moore MJ. 2002. Purification and characterization of native spliceosomes suitable for three-dimensional structural analysis. RNA 8:426-439.

Kaiser C, Michaelis S, Mitchell A. 1994. Methods in yeast genetics. Plainview, New York: Cold Spring Harbor Laboratory Press.
Konarska MM, Sharp PA. 1987. Interactions between small nuclear ribonucleoprotein particles in formation of spliceosomes. Cell 49:763-774.

Laemmli UK. 1970. Cleavage of structural proteins during the assembly of the head of bacteriophage T4. Nature 227:680-685.

Laggerbauer B, Achsel T, Lührmann R. 1998. The human U5-200kD DEXH-box protein unwinds U4/U6 RNA duplexes in vitro. Proc Natl Acad Sci USA 95:4188-4192.

Lauber J, Fabrizio P, Teigelkamp S, Lane WS, Hartmann E, Lührmann R. 1996. The HeLa 200 kDa U5 snRNP-specific protein and its homologue in $S$. cerevisiae are members of the DEXHbox protein family of putative RNA helicases. EMBO J 15:40014015.

Lindsey LA, Garcia-Blanco MA. 1998. Functional conservation of the human homolog of the yeast pre-mRNA splicing factor Prp17p. $J$ Biol Chem 273:32771-32775.

Lührmann R. 1988. snRNP proteins. In: Birnstiel ML, ed. Structure and function of major and minor small nuclear ribonucleoprotein particles. Berlin: Springer-Verlag. pp 71-99.

Lynch KW, Maniatis T. 1995. Synergistic interactions between two distinct elements of a regulated splicing enhancer. Genes \& Dev 9:284-293.

MacMillan AM, Query CC, Allerson CR, Chen S, Verdine GL, Sharp PA. 1994. Dynamic association of proteins with the pre-mRNA branch region. Genes \& Dev 8:3008-3020.

Maniatis T, Reed R. 2002. An extensive network of coupling among gene expression machines. Nature 416:499-506.

Maroney PA, Romfo CM, Nilsen TW. 2000. Functional recognition of the $5^{\prime}$ splice site by U4/U6.U5 tri-snRNP defines a novel ATPdependent step in early spliceosome assembly. Mol Cell 6: 317-328.

Mathews DH, Sabina J, Zuker M, Turner DH. 1999. Expanded sequence dependence of thermodynamic parameters improves prediction of RNA secondary structure. J Mol Biol 288:911-940.

Mathur M, Tucker PW, Samuels HH. 2001. PSF is a novel corepressor that mediates its effect through $\operatorname{Sin} 3 \mathrm{~A}$ and the DNA binding domain of nuclear hormone receptors. Mol Cell Biol 21:2298-2311.

McConnell TS, Steitz JA. 2001. Proximity of the invariant loop of U5 snRNA to the second intron residue during pre-mRNA splicing. EMBO J 20:3577-3586.

Meissner M, Dechat T, Gerner C, Grimm R, Foisner R, Sauermann G. 2000. Differential nuclear localization and nuclear matrix association of the splicing factors PSF and PTB. J Cell Biochem 76:559-566.

Miralles F, Öfverstedt L, Sabri N, Aissouni Y, Hellman U, Skoglund U, Visa N. 2000. Electron tomography reveals posttranscriptional binding of pre-mRNPs to specific fibers in the nucleoplasm. $J$ Cell Biol 148:271-282.

Monsalve M, Wu Z, Adelmant G, Puigserver P, Fan M, Spiegelman BM. 2000. Direct coupling of transcription and mRNA processing through the thermogenic coactivator PGC-1. Mol Cell 6:307-316.

Newman AJ. 1997. The role of U5 snRNP in pre-mRNA splicing. EMBO J 16:5797-5800.

Nilsen TW. 1998. RNA-RNA interactions in nuclear pre-mRNA splicing. In: Simons R, Grunberg-Manago M, eds. RNA Structure and function. Cold Spring Harbor, New York: Cold Spring Harbor Laboratory Press. pp 279-307.

O'Keefe RT, Newman AJ. 1998. Functional analysis of the U5 snRNA loop 1 in the second catalytic step of yeast pre-mRNA splicing. EMBO J 17:565-574.

Patton JG, Mayer SA, Tempst P, Nadal-Ginard B. 1991. Characterization and molecular cloning of Polypyrimidine Tract Binding Protein: A component of a complex necessary for pre-mRNA splicing. Genes \& Dev 5:1237-1251.

Patton JG, Porro EB, Galceran J, Tempst P, Nadal-Ginard B. 1993. Cloning and characterization of PSF, a novel pre-mRNA splicing factor. Genes \& Dev 7:393-406.

Patton JR. 1991. Pseudouridine modification of U5 RNA in ribonucleoprotein particles assembled in vitro. Mol Cell Biol 11: 5998-6006.

Pérez I, Lin C-H, McAfee JG, Patton JG. 1997. Mutation of PTB binding sites causes misregulation of $\alpha$-Tropomyosin alternative $3^{\prime}$ splice site selection in vivo. RNA 3:764-778.

Reed R. 2000. Mechanisms of fidelity in pre-mRNA splicing. Curr Opin Cell Biol 12:340-345. 
Reyes JL, Kois P, Konforti BB, Konarska MM. 1996. The canonical GU dinucleotide at the $5^{\prime}$ splice site is recognized by p220 of the U5 snRNP within the spliceosome. RNA 2:213-225.

Ségault V, Will CL, Polycarpou-Schwarz M, Mattaj IW, Branlant C, Lührmann R. 1999. Conserved loop I of U5 small nuclear RNA is dispensable for both catalytic steps of pre-mRNA splicing in HeLa nuclear extracts. Mol Cell Biol 19:2782-2790.

Sewer MB, Nguyen VQ, Huang CJ, Tucker PW, Kagawa N, Waterman MR. 2002. Transcriptional activation of human CYP17 in H295R adrenocortical cells depends on complex formation among p54(nrb)/NonO, protein-associated splicing factor, and SF-1, a complex that also participates in repression of transcription. Endocrinology 143:1280-1290.

Staley JP, Guthrie C. 1998. Mechanical devices of the spliceosome: Motors, clocks, springs, and things. Cell 92:315-326.

Steitz TA. 1999. RNA recognition by proteins. In: Gesteland RF, Cech TR, Atkins JF, eds. The RNA world. 2nd ed. Cold Spring Harbor, New York: Cold Spring Harbor Laboratory Press. pp 427-450.

Straub T, Grue P, Uhse A, Lisby M, Knudsen BR, Tange TO, Westergaard O, Boege F. 1998. The RNA-splicing factor PSF p54 controls DNA topoisomerase I activity by a direct interaction. J Biol Chem 273:26261-26264.

Straub T, Knudson BR, Boege F. 2000. PSF/p54 nrb stimulates "jumping" of DNA topoisomerase I between separate DNA helices. Biochem 39:7552-7558.

Swanson MS. 1995. Functions of nuclear pre-mRNA/mRNA binding proteins. In: Lamond Al, ed. Pre-mRNA processing. Austin, Texas: R.G. Landes Company. pp 17-34.

Szostak JW. 1992. In vitro genetics. Trends Biochem Sci 17:89-93.

Teigelkamp S, Mundt C, Achsel T, Will C, Lührmann R. 1997. The human U5 snRNP-specific $100 \mathrm{kD}$ protein is an RS domaincontaining, putative RNA helicase with significant homology to the yeast splicing factor Prp28p. RNA 3:1313-1326.

Traish AM, Huang YH, Ashba J, Pronovost M, Pavao M, McAneny DB, Moreland RB. 1997. Loss of expression of a $55 \mathrm{kDa}$ nuclear protein (nmt55) in estrogen receptor-negative human breast cancer. Diagn Mol Pathol 6:209-221.

Tuerk C, Gold L. 1990. Systematic evolution of ligands by exponen- tial enrichment: RNA ligands to bacteriophage T4 DNA polymerase. Science 249:505-510.

Urban RJ, Bodenburg Y, Kurosky A, Wood TG, Gasic S. 2000. Polypyrimidine tract-binding protein-associated splicing factor is a negative regulator of transcriptional activity of the porcine p450scc insulin-like growth factor response element. Mol Endocrinol 14:774-782.

Valcárcel J, Gaur RK, Singh R, Green MR. 1996. Interaction of U2AF65 RS region with pre-mRNA branch point and promotion of base pairing with U2 snRNA. Science 273:1706-1709.

Vijayraghavan U, Abelson J. 1990. PRP18, a protein required for the second reaction in pre-mRNA splicing. Mol Cell Biol 10:324-332.

Wurtz T, Kiseleva E, Nacheva G, Alzhanova-Ericcson A, Rosen A, Daneholt B. 1996. Identification of two RNA-binding proteins in Balbiani ring premessenger ribonucleoprotein granules and presence of these proteins in specific subsets of heterogeneous nuclear ribonucleoprotein particles. Mol Cell Biol 16:1425-1435.

Yang Y-S, Hanke JH, Carayannapoulos L, Craft CM, Capra JD, Tucker PW. 1993. NonO, a non-POU-domain-containing, octamer-binding protein, is the mammalian homolog of Drosophila nonA ${ }^{\text {diss }}$. Mol Cell Biol 13:5593-5603.

Zamore PD, Patton JG, Green MR. 1992. Cloning and domain structure of the mammalian splicing factor U2AF. Nature 355:609-614.

Zhang WW, Zhang LX, Busch RK, Farres J, Busch H. 1993. Purification and characterization of a DNA-binding heterodimer of 52 and $100 \mathrm{kDa}$ from HeLa cells. Biochem J 290:267-272.

Zhang Z, Carmichael GG. 2001. The fate of dsRNA in the nucleus: A p54nrb-containing complex mediates the nuclear retention of promiscuously A-to-I edited RNAs. Cell 106:465-475.

Zhou Z, Reed R. 1998. Human homologs of yeast Prp16 and Prp17 reveal conservation of the mechanism for catalytic step II of premRNA splicing. EMBO J 17:2095-2106.

Zuker M, Mathews DH, Turner DH. 1999. Algorithms and thermodynamics for RNA secondary structure prediction: A practical guide. In: Barciszewski J, Clark BFC, eds. RNA biochemistry and biotechnology. Dordrecht, The Netherlands: Kluwer Academic Publishers. pp 11-43. 